\title{
SPROKKELINGEN OP HET TERREIN DER GESCHIE- DENIS VAN DE NEDERLANDSCHE ANTILLEN
}

DOOR

\section{W. R. MENKMAN}

Er was in het herdenkingsjaar 1934 meer aanleiding dan ooit te voren om zich te verdiepen in de geschiedenis der Nederlandsche vestigingen in de Caraibische Zee en velen hebben zich, blijkens de verschenen publicaties, tot de bestudeering van dit hoofdstuk onzer koloniale historie aangetrokken gevoeld.

Het is niet het belangrijkste hoofdstuk, omdat het gebied, waarop het betrekking heeft, het kleinste is onzer tegenwoordige overzeesche gewesten, maar het stelt geheel aparte eischen aan de belangstelling van den lezer. Het onderscheidt zich in dit opzicht van de andere hoofdstukken, dat de eilandjes, waarvan het de lotgevallen verhaalt, in zoo sterke mate den invloed ondergingen, politiek, cultureel en economisch, van de omgeving, waarin zij geplaatst zijn. Veel meer dan Suriname, dat overigens in zoover met de Antillen overeenkomt, dat beide gebieden tot de nieuwe wereld behooren, waar alle tegenwoordige politieke eenheden haar historisch leven als Europeesche volkplantingen begonnen zijn.

Onze eilanden immers zijn gelegen in een zeegebied, waarin gedurende twee en een halve eeuw Westeuropeeschemogendheden een bitteren strijd gestreden hebben, een strijd waarin het eigen moederland òf een ondergeschikte, òf in het geheel géén rol speelde. Wie dus de geschiedenis onzer Beneden- en Bovenwindsche eilanden wil begrijpen, moet zich telkens rekenschap er van geven, hoe de verhouding was van andere Europeesche landen, ten opzichte van elkaar en ten opzichte van hun Amerikaansche koloniën.

Hiaten, onduidelijkheden, tegenstrijdigheden, niet op bevredigende wijze toegelichte bijzonderheden en aperte onjuistheden, komen in iedere geschreven geschiedenis voor; door vergelijking 
der eene bron met de andere moeten de leemten zoo veel mogelijk worden aangevuld.

Wat betreft de geschiedenis der Nederlandsche Antillen was er een gereede aanleiding voor zoodanige vergelijking en aanvulling, toen in 1934 deze eilanden en hun verleden in verschillende publicaties behandeld werden, zonder dat het nochtans tot een geheel nieuwe bewerking kwam der historie van het tegenwoordige gebiedsdeel Curaçao,

Zoolang niemand een arbeid als laatstbedoeld ter hand neemt, kan het m.i. nuttig zijn, gegevens en bouwstoffen te verzamelen en die onder de oogen te brengen van hen die in Westindische aangelegenheden in het algemeen belang stellen.

De samenstelling der Encyclopaedie van Nederlandsch WestIndië werd twintig jaar geleden aangevangen en in 1917 beëindigd; een aanvulling is tot dusver niet verschenen. Tot op zekere hoogte evenwel zou de West-Indische Gids (de eerste jaargang verscheen in 1919) als een voortzetting kunnen gelden, ook wat betreft historische gegevens; niet het minst wegens de geregeld in ons tijdschrift opgenomen boekbesprekingen en bibliographieën.

Ik heb mij afgevraagd, of de hieronder alphabetisch gerangschikte aanteekeningen in onze Gids, die geen encyclopaedie is en geen historisch woordenboek, toch niet op haar plaats zouden zijn.

Misschien dat de publicatie dier aanteekeningen ertoe kan strekken, hier en daar iets op te helderen, misschien dat zij aanleiding kan geven tot vruchtbare gedachtenwisseling, of anderen zal opwekken tot het aandragen van nieuwe stof.

Ampies of Ampuies. Amelunxen (De geschiedenis van Curaçao opnieuw verteld) wijkt van deze door de Nederlandsche auteurs meest gevolgde schrijfwijze af en noemt dezen Spanjaard Ampiès (of Ampuez). Nu doet de spelling weinig ter zake, maar de accentuatie is van belang. De Enciclopedia universal ilustrada Europeo-Americana schrijft Ampués, desgelijks de Heer G. J. van Grol in het in 1934 verschenen eerste deel zijner Grondpolitiek in het West-Indische Domein der Generaliteit.

Simons (Beschrijving van Het Eiland Curaçao) noemt den man Jean de Ampeuz en volgt daarin Teenstra na (Ned. W. I. Eilanden). Uit wat eerstgenoemde schrijft zou men den indruk kunnen krijgen dat, toen de Nederlanders op Curaçao kwamen, Ampués 
nog gold als de vorige gouverneur; hij moet toen echter al omstreeks een eeuw dood geweest zijn.

$\mathrm{Er}$ is een brief bekend van Juan de Ampués, „fator de V. M. „é Su Regidor en esta Ciudad de Santo Domingo", waarin hij aan Karel V mededeelde, hoe in 1513 „el Rey Católico” aan Sto Domingo en aan San Juan (Puerto Rico) had toegestaan, zich de bewoners van verschillende „islas inútiles” (eilanden waar geen rijkdommen te vinden waren) toe te eigenen. P. A. Euwens O.P. vertelt ons (Gedenkboek Nederland-Curaçao 1634 -1934), dat ten gevolge van deze vergunning ook onze Benedenwindsche eilanden hun indiaansche bevolking verloren, maar dat (dank zij Juan de Ampués) later een gedeelte mocht terugkeeren.

Reeds in 1517 schreven de Padres Priores de San Jerónimo aan den Cardinaal Cisneros, om de wenschelijkheid te bepleiten den „factor Juan de Ampiés” met een opdracht naar de vaste kust te zenden, in verband met aldaar voorkomende misbruiken (Documenten gepubliceerd door Luis Torres de Mendoza).

Tien jaren later stak Ampués inderdaad, op last der Audiencia van Santo Domingo, naar de Coriaansche kust over en hij stichtte op den dag van zijn aankomst (Sint Anna dag) de stad Coro. Bekend is hoe reeds op 24 Februari 1529 het eerste gezelschap Europeesche immigranten onder een agent der Welsers te Coro aankwam en hoe Ampués, gehoorzaam aan den last zijns Konings, maar met een bloedend hart, het terrein zijner werkzaamheid moest verlaten. De eilanden der Reuzen (Curaçao, Aruba en Bonaire) waren niet in de concessie begrepen, maar gereserveerd, als een Koninklijke schenking aan Juan de Ampués, wiens erfgenamen na hem de heerlijke rechten hebben bezeten.

Of Juan inderdaad op Curaçao is gaan wonen? Volgens José de Oviedo y Baños (Historia de la conquista y población de Venezuela) zou hij zich, diep gegriefd en teleurgesteld, voor de rest van zijn leven in Santo Domingo hebben teruggetrokken.

Zie Welsers.

Antillen, de naam. (C. K. Kesler, West-Indische Gids VIII, 567). Behalve van Antilha, Antilia, Antillia of Antiglia kan de naam Antillas ook nog afkomstig zijn van ante islas (vóóreilanden). Verschillende schrijvers geven deze laatste afleiding, o.a. de vertaler van het werk van Père Labat (W. G. Dycks, Amsterdam 1725), De Rochefort (Histoire naturelle et morale des Isles Antilles de l'Amérique), Cornelius de Jong (Reize naar de Carai- 
bische Eilanden in de jaren 1780 en 1781) en Hering (Beschrijving van het eiland Curaçao).

De Spanjaarden immers waren eenige malen op de eilanden geweest, voordat zij Tierra Firme ontdekten; Columbus zag de vaste kust voor het eerst toen hij in 1498, bij Trinidad langs, door de Boca del Sierpe en de Boca del Dragón, de Caraibische Zee voor de derde maal binnenvoer. Met betrekking tot de vaart van Europa lagen de Caraibische eilanden vóór het vasteland en in den naam Antillen zou dus niet alleen een herinnering zijn verscholen aan een legendarisch gebied, maar die naam zou tevens een geographische beteekenis hebben.

Archieven. Simons (Beschrijving van Het Eiland Curaçao) vertelde in 1868, dat bij de inlijving van 1810 de archieven der West-Indische Compagnie naar Frankrijk zouden zijn overgebracht (de politieke naar Parijs, de commercieele naar Bordeaux) en dat zij niet zouden zijn teruggekomen.

In het Alg. Rijksarchief bleken geen aanwijzingen te vinden voor de juistheid dezer bewering, wel voor het tegendeel.

Het archief der Kamer Amsterdam berustte in 1828 in het Westindisch pakhuis aldaar ('s Gravenhekje); met deze verzameling werd in 1851 vereenigd het archief der Kamer Zeeland, uit Middelburg naar Amsterdam overgebracht (inlichtingen Alg. Rijksarchivaris).

Armazoen. Een lading negerslaven heette een armazoen, niet een cargasoen (verg. C. K. Kesler, West-Indische Gids IX, 153). In de oorspronkelijke, algemeene, beteekenis van uitrusting (Sp. armazón, Port. armaçao) werd het woord armazoen gebruikt in de aloude Groenlandvaart (Woordenboek der Nederlandsch Taal).

Zie Cargasoen.

Aruba. Ojeda en de zijnen noemden dit eiland „y de brasil" (verfhouteiland) en onder dezen naam komt het ook voor op de kaart van Juan de la Cosa, die er evenwel een anderen, waarschijnlijk indiaanschen naam aan toevoegde, t.w. „Gujan" ( $\mathrm{J}$. G. Kohl, Die beiden ältesten General-Karten von Amerika).

In den Ptolemaeus van 1513 echter vinden wij het eiland ten Oosten van dat der Reuzen ,y do brassil" genoemd, dus Bonaire, dat ook later, meer dan Aruba, het verfhouteiland was.

Exquemelin vertelt in zijn zeerooversboek, dat Morgan, op weg naar Maracaibo, Curaçao gepasseerd zijnde, 't naar „Ruba” 
liet „sacken” en daar twee dagen bleef. E. geeft een beschrijving van Aruba, welke op eigen waarneming kan berust hebben, want hij maakte den tocht mede.

Henry Morgan voer in het begin van 1669 van Jamaica uit, voor den strooptocht langs de vaste kust (Dictionary of National Biography) en Exquemelin neemt in zijn boek een brief over „van den Spaenschen Generael Don Alonzo del Campo Spinoce, „aen Morgan, Admirael van de Rovers”, gedagteekend aan boord van een „Koninghs Schip, genaemt de Magdaleen, leggende ten „ancker in de mondt van de Lagon van Maracaibo, den 24 April „1669".

De mededeeling van Bosch (Reizen in West-Indië), dat eerst in het begin der 18e eeuw de Nederlandsche vlag op Aruba geplant zou zijn en onderofficieren van het Curaçaosche garnizoen er toen als posthouders zouden zijn gedetacheerd, kan dus niet juist zijn. Exquemelin zegt dat het eiland ,onder de Westindische „Maetschappy behoort, die daer een Sergeant stelt als Gouver„neur, met vijftien soldaten".

Asiento. Niet assiento (verg. C. K. Kesler, West-Indische Gids IX, 152 en Isaac le Long, Koophandel van Amsterdam, 1780, III).

De West-Indische Compagnie heeft wel met de asentistas gecontracteerd voor de levering van slaven, maar is zelf nooit houdster van het asiento geweest (verg. A. Hallema, West-Indische Gids XVI, 198).

Welk verband bestaat er tusschen het slavenasiento en den naam der voormalige plantage Asiento aan het Schottegat op Curaçao?

Aves, dat niet 30 mijl, maar circa twee maal zoo ver, ten Zuiden van Saba ligt, werd in 1865 in een arbitrale uitspraak door den Koning van Spanje verklaard rechtens tot Venezuela te behooren (Corporaal, De internationaalrechtelijke betrekkingen tusschen Nederland en Venezuela).

Hamelberg wil ons doen gelooven, dat deze uitspraak op een vergissing kan hebben berust, d.w.z. dat de arbiter het oog op de Zuidelijke Aves - die onder de Venezolaansche kust - gehad zou kunnen hebben. Een veronderstelling zóó naief, dat zij geen verdere aandacht verdient.

Intusschen was des Konings uitspraak natuurlijk alleen bindend tusschen Nederland en Venezuela en, volgens een mededeeling der Royal Geographical Society, werd Aves in Augustus 
1904 door Engeland geannexeerd. In ieder geval komt het op verschillende kaarten voor als „Bird Island (BR.)”. In de laatste editie evenwel van de kaart, uitgegeven door den Hydrographer of the Admiralty (1914), is het Aves - of zijn de Aves - in kwestie (circa 100 mijl ten $Z$. W. van Montserrat) aangegeven als Venezolaansch grondgebied.

De abt De la Porte schreef in 1751 ,les Hollandois possèdent "les isles d'Aves, de Buenaire, d'Aruba et de Curaço" en Van Paddenburgh vertelde (1819) dat „Roca, Orchilla en Sola d'Aves” slechts door Nederlanders bezocht werden (voor het zoeken van boebie-eieren), zoodat deze eilandjes soms bij Curaçao gerekend werden. In het Aardrijkskundig Woordenboek eindelijk van A. $\mathrm{J}$. van der Aa vinden wij vermeld dat het onbekend was (in 1839) of de Aveseilanden tot Venezuela of tot Curaçao behoorden. Ook de nationaliteit der Zuidelijke Aves is dus lang kwestieus gebleven. Van Dissel schreef in 1868 nog over de Nederlandsche Aves eilanden en bedoelde daarmede de Zuidelijke.

De Baas. Deze weinig Fransch aandoende naam staat, zonder voorletters, onder de beide stukken in het pamphlet, bewaard o.a. in de Koloniale Boekerij te Paramaribo, betreffende den Franschen aanslag op Curaçao van 1673 (Oudschans Dentz, West-Indische Gids VII, 279). Ook Hamelberg wijdt niet over De Baas uit.

Drie zeventiende eeuwsche dragers van den naam De Baas (De Baasz) zijn in verschillende encyclopaedieën te vinden en dan natuurlijk in de $18 \mathrm{e}$ eeuw Jean Pierre Louis, Baron de St. Croix de Batz, die Lodewijk XVI en Marie Antoinette van het schavot heeft trachten te redden.

Charles de Baatz, Seigneur d'Artagnan, de Gascogner die Dumas tot model heeft gediend voor een zijner mousquetaires, sneuvelde in 1673 voor Maastricht.

Paul Baron de B., gewezen mousquetaire van Mazarin, werd in 1654, na de mislukking zijner onderhandelingen met Cromwell, uit Engeland uitgewezen.

Jean Charles de B. ten slotte (broeder van den voorgaande?), de luitenant-generaal, was in 1668 op Martinique, als gouverneur der Fransche Antillen. Tegen hem werden vele klachten ingebracht, omdat hij den Hollandschen en Curaçaoschen handel niet tegenging, zooals hem door Colbert was opgedragen. De Fransche West-Indische Compagnie echter verlangde juist het tegenovergestelde van hem (Stewart L. Mims, Colbert's West India Policy). 
DeB's weinig vijandig optreden op Curaçao in 1673 (een rodomontade, een blufferij, noemt een pamphlet uit dien tijd dat optreden) wordt wellicht door het bovenstaande verklaard.

Zie Doncker.

Beck, Matthias. Directeur van 1664-1668 (W. R. Menkman, Geschiedkundige Atlas van Nederland; West-Indië; het eiland Curaçao). Deze jaartallen vindt men ook elders (o.a. bij W. M. Hoyer, Almanaque de Curaçao); natuurlijk hebben zij betrekking op Beck's zelfstandig directeurschap .Te voren was hij vicecommandeur of vice-directeur, onder Stuyvesant, die als directeur te Nieuw-Amsterdam resideerde. Vermoedelijk volgde Beck in 1655 Lucas Rodenburgh op.

Knappert (Gedenkboek Nederland-Curaçao 1634 - 1934) vond in 1659 Matthias Soock en meende daarmede een tot dusver nog niet genoemden landvoogd te hebben ontdekt. Ds. Van Beaumont echter zal misschien wat onduidelijk hebben geschreven, zoodat Beck kan worden gelezen als Soock.

Beneden- en bovenwinds. Op Curaçao is nog altijd de invloed sterk, welke de vrijwel constant waaiende Noordoostpassaat van oudsher op de plaatsbepaling uitoefent. Ook mechanisch voortbewogen vaartuigen komen „van boven” wanneer zij uit Oostelijke, „van beneden” wanneer zij uit Westelijke richting op het eiland aanhouden. Twee regenbakken, bij hetzelfde huis behoorend, worden „rehenbaak di riba” en „rehenbaak di abau” genoemd, wanneer de eene ten Oosten en de andere ten Westen van het huis staat.

Exquemelin, die ons vertelt hoe Franschen van St. Christophe zich op Tortuga neerzetten, spreekt eenige malen van meer volk en van hulp, „van boven” gerequireerd; St. Kitts ligt wèl 3 graden Zuidelijker, maar tevens 10 graden Oostelijker dan Tortuga. Reeds de Spanjaarden waren begonnen met de onderscheiding boven en beneden toe te passen op de plaatsen in de Caraibische Zee; islas de barlovento, van Trinidad tot, of tot en met, Porto Rico, islas de sotavento, van Margarita tot en met Aruba.

Zooals bekend is, doen de Engelschen anders; zij verdeelen de eilanden, gelegen in denzelfden boog, welke ten opzichte van het vasteland geheel bovenwinds is, in Leeward en Windward Islands. Elisée Reclus (Nouvelle Géographie universelle, 1891) noemt dit systeem foutief. Geheel in overeenstemming met de Engelsche onderscheiding evenwel sprak A. H. Bisschop Grevelink (een oud-marine officier) van St. Eustatius als behoorende 
tot de „benedenwindsche Karibische eilanden” (Beschrijving van St. Eustatius, Bijdragen tot de kennis der Nederl. en Vreemde Koloniën, 1846). De Rochefort kende negen belangrijke eilanden welke, ten opzichte van St. Christophe, benedenwinds liggen.

De hooger genoemde Spaansche indeeling is toegepast in het kaartje der Caraibische Zee, dat Brensa in zijn Beschouwingen van een toerist opnam.

Boekaniers worden vaak in één adem genoemd met flibustiers; inderdaad zullen de groep der zeeroovers en die der jagers wel niet scherp van elkander te scheiden zijn geweest. Zeeroovers zullen ter afwisseling zich wel bij de jagers hebben aangesloten en uit deze laatsten zullen vaak manschappen voor de roofschepen zijn gerecruteerd.

De boekaniers echter oefenden een afzonderlijk bedrijf uit (levering van vleesch aan plantages en schepen) en Exquemelin (1678) noemt hen Stieren jagers, terwijl hij voor de flibustiers geen anderen naam dan dien van zeeroovers kent.

Ook Père Labat houdt jagers en zeeschuimers uit elkander en hij laat eveneens uitkomen, dat niet alleen het vleesch van wilde runderen geboekaneerd werd. Ook de door de Europeanen op de eilanden losgelaten zwijnen verwilderen (precies zooals, later, in de Stille Zuidzee) en leverden jachtwild op. De boucán diende niet enkel tot het toebereiden van vleesch (zie De Rochefort).

Zie Bok.

Bok. Bokjes werden te Batavia de leden der Boegineesche kolonie genoemd, Bokkenees is eveneens een verbastering van Boeginees, bokkenier dito van boekanier (Woordenboek der Nederl. Taal). Zie ook de levensbeschrijving van Jan Erasmus Reining, door D. v. d. Sterre, 1691.

Hoe kwamen echter de Engelschen in Noord-Amerika aan den naam buck voor een mannelijk Indiaan of neger (Webster, New international dictionary of the English language)?

Ook in de Nederlandsche koloniën op het vasteland van ZuidAmerika, noemde men de Indianen bokken (De Villiers, Storm van 's Gravesande).

Op St. Eustatius kwamen in 1729 nog indiaansche slaven voor (Knappert, W. I. Gids, XI, 369).

Bonaire. In De Laet's Iaerlijck Verhael wordt Bonaire voor het eerst genoemd als bezocht door Boudewijn Hendricksz. (1626); 
Wassenaer maakt melding van het kappen van verfhout op dit eiland door Nederlanders in 1623.

Beide gevallen dus enkele jaren ná de oprichting der WestIndische Comp. (verg. W. R. Menkman, Tijdschrift voor Economische Geographie, 25e jaargang, 246).

La Borde. Ds. Bosch herinnerde zich dat La Borde met zijn smaldeel, dat het garnizoen van Puerto Cabello aan boord had, voor Curaçao verscheen; het Curaçaosche volk riep „viva Co„,lombia”. (Reizen in W.I., 1829).

Corporaal schrijft ook over een bezoek van La Borde aan Curaçao, in 1828, in verband met de afscheidingsbeweging in Venezuela, een bezoek dat Van den Bosch, die van 10 December 1827 tot Maart 1828 op Curaçao vertoefde, niet kon voorkomen. De brief van Van den Bosch dienaangaande van 13 Februari 1828 komt niet voor in den bundel, opgenomen in de Bijdragen en Mededeelingen van het Historisch Genootschap, LI (Mr. B. de Gaay Fortman).

Bovenwindsche eilanden. De Nederlandsche geschiedenis dezer eilanden vangt niet, zooals die der Benedenwindsche, met een historisch vaststaande gebeurtenis aan.

Wel schreef Ds. G. B. Bosch dat St. Eustatius sedert 1639 en dat St. Maarten sedert 1638 of 1639 Nederlandsch is, maar de auteur der Reizen in W.I. vertelt er niet bij hoe hij aan die jaartallen is gekomen.

In onze geschiedenis zijn bekend de verovering van St. Eustatius door de Franschen in 1690, het afslaan van den aanval van één Fransch kaperschip op Saba en de herovering van St. Eustatius in hetzelfde jaar van af Saba. P. Labat vermeldt echter een aanval met één schip op Saba in 1688 en geeft den naam van den Franschen kaperkapitein als Pinel.

Van 1782-1784 stonden volgens Bisschop Grevelink (Beschrijving van St. Eustatius) de Bovenwindsche eilanden onder Charles Fitz Maurice als militair en Charles Chabert als civiel gouverneur. G. Lacour-Gayet (La marine militaire de la France sous le règne de Louis XVI) vertelt dat François Claude, marquis de Bouillé, gouverneur général des îles du vent, op 15 November 1781 met 8 schepen (onder Ch. de Girardin) van Martinique uitzeilde en op den 25 en d.a.v. in den morgen St. Eustatius bij verrassing op de Engelschen veroverde. Bouillé liet den vicomte de Damas als bevelhebber achter. 
Volgens den brief welken Joh. de Graaff - toen ambteloos burger - op 13 Januari 1783 naar Amsterdam schreef, was destijds Charles Chabert „opperhoofd” op St. Eustatius, met 900 man garnizoen.

Op 7 Februari 1784 (brief der Raden van St. Eustatius van 13 Maart 1784) werd St. Eustatius van de Franschen overgenomen (St. Maarten 11 Februari) en het protocol der overgave werd onderteekend door Thomas de Fitz Maurice, lieutenant colonel d'infanterie, chef des forces militaires des isles St. Eustache, Saba et St. Martin, en vertu des pouvoirs à nous donnés par monsieur le vicomte Damas, gouverneur général des isles françaises du vent.

De secretaris B. Grevelink maakt melding van de onvermoeide pogingen en de groote uitgaven, onder de regeering van Koning Lodewijk besteed aan de defensie van St. Eustatius en zegt dat de komst der Engelschen lang te voren was aangekondigd; toch verklaarde de bevelhebber dat er gebrek was aan kruit, ammunitie en manschappen.

Brazilië. Hamelberg wil het doen voorkomen alsof in het voorjaar van 1634 de gelegenheid voor een aanslag op Curaçao bijzonder gunstig was, omdat men sedert den zomer van 1633 een groote onderneming tegen Brazilië voorbereidde; anderen hebben dit den genoemden auteur nageschreven.

Of die onderneming is doorgegaan echter en waarin zij bestond, wordt nergens verteld en het verband met de expeditie naar Curaçao is nooit aangetoond.

Brion, Pedro Luis. Hoe langer zoo meer wordt het gewoonte Brion voor te stellen als Curaçao's nationale held.

Afgezien van het bezwaar, dat ingebracht zou kunnen worden tegen het woord nationaal met betrekking tot het eiland Curaçao, dient bedacht te worden, dat vereering van Brion als Nederlander en Curaçaoenaar alleen gegrond kan zijn op zijn verdiensten ten aanzien der handhaving van de Nederlandsche souvereiniteit op de Benedenwindsche eilanden, in de moeilijke jaren tusschen 1803 en 1807.

Toen in 1816 de Nederlandsche vlag weder op Curaçao geheschen werd, was Brion al sedert eenige jaren geen Nederlander meer, maar Venezolaansch burger.

Brion heeft, zooals bekend is, eerst aan Venezuela, later aan de grootere republiek Colombia, belangrijke diensten bewezen, in den strijd tegen Spanje, maar de eer welke hem daarvoor te 
beurt gevallen is, kan voor Curaçao alleen streelend zijn omdat hij van het eiland geboortig was.

Als admiraal der independenten kon Brion hoogstens trachten excessen te voorkomen, hetzij in het algemeen, hetzij tegenover schepen onder Nederlandsche vlag in het bijzonder. Overigens kon zijn houding tegenover Curaçao, dat diensten verleende aan de Spaansche zaak en tegenover het Curaçaosche gouvernement, dat gebonden was door de politiek der Nederlandsche regeering, die voorloopig geen Zuidamerikaansche republieken kon erkennen, geen andere zijn dan die van tegenstander. De gouverneurgeneraal Kikkert meende dan ook zich over Brion te beklagen te hebben. (zie Corporaal, Internationaalrechtelijke betrekkingen).

Waarom verbastert Van Paddenburgh Brion's naam tot Brias?

Brisbane, Sir Charles, overleden 1829. De veroveraar van $\mathrm{Cu}-$ raçao (1 Januari 1807) werd later gouverneur van St. Vincent. Een portret van Brisbane (met opgeheven degen den fortmuur op Curaçao beklimmend) is in het bezit van den Heer R. Brisbane Wilson te Dugald, Manitoba, Canada.

Op 16 Maart 1934 bezocht de Britsche kruiser „Curaçao" de haven van Amsterdam. Dit schip voerde als ,,badge" het wapen van Brisbane (kop van een ooievaar op een zwart veld, met een groene slang in de bek) met het devies "certamine summo" (in het hevigst van den slag). Alg. Handelsblad.

Bylandt, Van. Dr. F. W. van Wijk (De Republiek en Amerika, 1776 - 1782) noemt in zijn index de beide Van Bylandts niet afzonderlijk; ook Fr. Edler (The Dutch Republic and the American Revolution) doet dat niet, maar houdt in den tekst toch den schout bij nacht en den kapitein ter zee uit elkaar.

Van Wijk echter zegt op blz. 123 dat het fregat Mars, dat op 3 Februari 1781 ter reede van St. Eustatius de vlag moest strijken, door den schout bij nacht Van B. werd gecommandeerd, denzelfden die op 31 December 1779 bij Wight door Fielding was aangehouden.

De commandant echter van de „kleine” Mars was de kapitein ter zee Frederick Sigismund van Bylandt, de onfortuinlijke vlootvoogd van 1779 de schout bij nacht Lodewijk van Bylandt, in de Statiaansche geschiedenis bekend door het „tumult" van April 1778. 
Burgeroorlog, Amerikaansche. Deze had eenigen - ongunstigen - invloed op den toestand onzer eilanden, wegens belemmering van het handelsverkeer; in 1861 werd de zeemacht op Curaçao tijdelijk versterkt. Wegens de hulp, in laatstgenoemd jaar op het eiland verleend aan een gewapend vaartuig der Zuidelijken, liet de Nederlandsche Regeering aan die te Washington excuses aanbieden.

Tijdelijke handelsvoordeelen vielen er uit het conflict op het Noordamerikaansche vasteland voor de Nederlandsche Antillen niet te trekken; voor de blokkadebrekers, die het verkeer der havens van de Zuidelijken trachtten in stand te houden, waren Nassau op de Bahama's en Hamilton op Bermuda de centra (verg. W. R. Menkman, Tijdschrift voor Economische Geographie, 25e jaargang, 250).

Caraboo. Teenstra (Ned. W. I. Eilanden) verwijst naar Picary, Detail of the Case of the Brig Caraboo of Liverpool 1828.

Dit was het Engelsche schip dat, op weg van Liverpool naar Buenos Aires, met stukgoed en passagiers, door den kaper Damas de Argentina (vroeger Patagonia) werd genomen op 21 Juli 1828, "within the jurisdiction of the Admiralty of England", d.w.z. 200 mijl van de Canarische eilanden.

De Caraboo zou, volgens de Britsche regeering, naar St. Eustatius zijn opgebracht, ten verkoop, waar, ook volgens de Fransche autoriteiten, kapers zouden worden begunstigd, evenals op St. Barth's en St. Thomas, van wege de voordeelige zaken welke de kooplieden ter plaatse met de door feitelijken zeeroof verkregen goederen konden doen. De Caraboo was waarschijnlijk op Saba aangebracht, daar verlaten en later op last der Statiaansche autoriteiten naar St. Eustatius overgebracht.

De Damas werd genomen door de Victor - captain Lloyd - en de bemanning stond op St. Kitts terecht (Gedenkboek Nederland-Curaçao 1634-1934, 97).

Mr. B. de Gaay Fortman (Bijdr. en Meded. Hist. Gen. LI) neemt één brief ter zake op van Van den Bosch, gedagteekend 's Gravenhage 9 Maart 1829. Het Caraboo-dossier in het Alg. Rijksarchief bevat nog eenige andere brieven van den generaal over deze aangelegenheid (8 November 1828 aan Marine en Koloniën en 5 December 1828 aan Buitenl. Zaken) alsmede een brief aan den gouverneur-generaal te Paramaribo van 18 Juli 1828 aangaande Fransche klachten in zake begunstiging van zeeroof op de drie Nederlandsche Bovenwindsche eilanden. 
De Zuidamerikaansche staten, die in den strijd tegen Spanje geen officieele marine in zee konden brengen, gaven op gemakkelijke voorwaarden kapercommissies en officierspatenten uit en het waren vooral Bostonsche reederijen die daarvan gebruik maakten. Engeland en Frankrijk namen soms een eigenaardigehouding tegenover deze kapers (eigenlijk zeeroovers) aan, zoolang haar eigen koopvaardij er geen last van had, de kapers ontzagen de vlaggen der kleine koloniale mogendheden, wegens de hulp welke zij op de Deensche, Nederlandsche en Zweedsche Westindische eilanden genoten en .... Nederland had geen krachtige marine in de Caraibische Zee.

Caracas. Werd vroeger ook geschreven Caraques of Krakes, waardoor de gedachte wordt gewekt aan de caraques, of caracas, de groote Portugeesche en Spaansche schepen, welke de Nederlanders kraken noemden en de Portugeezen reeds in het begin der $17 \mathrm{e}$ eeuw door de lichtere galeones begonnen te vervangen (Wassenaer, Historisch verhael, 1623).

De Caracasbaai op Curaçao kon inderdaad groote schepen herbergen (verg. Onze West, derde druk, bladz. 93), maar het ligt meer voor de hand, dat die baai haar naam kreeg omdat schepen van de tegenoverliggende kust hier een veilige schuilplaats vonden (Bosch, Reizen in West-Indië). De door de conquistadores onderworpen Caracas hebben hun naam gegeven aan het kustgebied, aan een dichtbevolkte landstreek en aan een vallei, welke ook Valle de San Francisco heetten. Op de plaats der stad San Francisco (gesticht in 1560) verrees zeven jaar later Santiago de Leon de Caracas, de tegenwoordige hoofdstad van Venezuela.

Intusschen heet de beste haven van Ecuador, aan de Westkust van Zuid-Amerika, Bahia de Caraques.

Zie Scheepstypen.

Cargasoen. (Sp. cargazón), een lading koopmanschappen.

Zie Armazoen.

Cartelschip, Kartelschip. Een schip waarmede krijgsgevangenen werden overgebracht. Pitnam spreekt van flags of truce and cartels.

Zie Vlag, vredes.

St. Christophe (St. Kitts) De Ruyter laadde hier in 1645 tabak en Blok (Michiel Adriaansz. de Ruyter) noemt het een Engelsch eiland. 
De handel van Nederlandsche schippers met de Fransche kolonisten van het eiland bestond reeds geruimen tijd eerder (zie o.a. Hamelberg).

Met Thomas Warner, die in 1623 op St. Kitts landde, wordt de relatie van het eiland met Europa geacht te zijn aangevangen; deze Engelschman echter werd spoedig gevolgd door den Franschen kaperkapitein Desnambuc (The Nations of to-day, British America) en in 1628 arriveerde Guillaume d'Orange, uitgezonden door de in 1626 opgerichte Société de Saint Christophe, ter versterking der bestaande Fransche vestiging (Vicomte de Mothey, Guillaume d'Orange). De kolonisten (Engelschen, Franschen en Nederlanders) werden in 1629 door de Spanjaarden verdreven, maar keerden terug.

St. Kitts behoorde tot die eilanden, welke in 1627 door Jacobus I aan den hertog van Carlisle waren toegewezen, maar de Engelsche en de Fransche kolonisten verdeelden het eiland onder elkaar, zooals Nederlanders en Franschen in 1648 met St. Maarten deden. (Zie ook De Rochefort).

In 1635 werd de Fransche West-Indische Compagnie opgericht en hield de Société de St. Christophe op te bestaan.

De Franschen maakten zich in 1666 van het geheele eiland meester, maar bij den vrede van Breda werd het weder gemeenschappelijk Fransch-Engelsch bezit; in 1689 werd het omstreden gebied, totdat het in 1713, bij den vrede van Utrecht, in zijn geheel en voor goed Engelsch werd.

Commandeur. De beteekenis van dezen titel is niet altijd goed begrepen.

In de eerste plaats was tot en met de $18 \mathrm{e}$ eeuw de commandeur de gezaghebber over een klein eiland, of een ondergeschikt gebiedsdeel (commandeur van St. Eustatius, vice-commandeur van St. Maarten en Saba, commandeur van Demerary). Amelunxen (blz. 45) spreekt van Binckes als commandeur van Tobago; de kapitein Jacob Binckes was echter, met den titel van commandeur, bevelhebber over het Hollandsche eskader, dat in Maart 1676 van Texel uitliep naar West-Indië. De expeditie was hoofdzakelijk tegen de Fransche Antillen gericht en B. had o.a. opdracht om Tobago in bezit te nemen en aldaar een nieuwe Nederlandsche volkplanting te vestigen.

$\mathrm{Na}$ den Engelsche tijd sprak men ook wel van commandant of kommandant (,en hebben den heer commandant S. B. van den „Broeck op de plechtigste wijze aan de ingezetenen voorge- 
„steld”, rapport overname eiland Bonaire 28 Mei 1816, medegedeeld door Dr. J. de Hullu, West-Indische Gids IV, 505). In Natal, op Sumatra, werd een Nederlandsch bestuursambtenaar in 1842 nog toewan kommandeur genoemd (Max Havelaar, aanteekeningen).

Verder was commandeur in de $17 \mathrm{e}$ en $18 \mathrm{e}$ eeuw synoniem met commandant, in den zin van militair bevelhebber, een functie dus, geen rang; van een aanzienlijk bezettingsleger noemde men den opperbevelhebber gouverneur (den colonel Van Waerdenburgh in Brazilië b.v.). Pierre Le Grand, die in Brazilië van kapitein tot (sergeant) majoor was bevorderd, vergezelde in 1634 Van Walbeeck als commandeur over de soldaten. Nog in de $18 \mathrm{e}$ eeuw werd van den troepen- of garnizoenscommandant in een Compagniesgebied gesproken als van den commandeur. Storm van 's Gravesande schreef in 1772 over den Commandeur der Militie en De Villiers (Storm van 's Gravesande. Zijn werk en zijn leven) teekent hierbij aan dat de directeur-generaal dikwijls met de titulatuur in de war is en dat men hier commandant moet lezen. De oud-militair Storm zal het echter wel bij het rechte eind hebben gehad.

Ten slotte was de commandeurstitel nog in gebruik bij de zeemacht; de bevelhebber over een klein eskader, of over een onderdeel eener vloot, heette commandeur. Verschillende titels hadden destijds een andere beteekenis dan tegenwoordig. De opperbevelhebber eener groote expeditie over zee heette generaal, ook al was hij, zooals Piet Heyn, naar onze opvattingen een zeeman; bij de landmacht dienden nog in de $18 \mathrm{e}$ eeuw adelborsten.

Onder de verschillende eskaders, die in Augustus tot November 1629 uitliepen, den ,generaal” Loncq achterop, was er een van vier schepen, elk onder een kapitein, maar het geheel onder een commandeur (Marten Valck) en een vice-commandeur (Johannes van Walbeeck). Laatstgenoemde kwam in April 1630 in Brazilië aan, ditmaal als commandeur, met vier schepen, welke tevens ruim 70 soldaten overbrachten. Hamelberg, die deze beide episoden uit de loopbaan van Van Walbeeck niet goed uit elkaar heeft gehouden, noemt Van W. commandeur der soldaten en anderen hebben het hem nagezegd; toch stellig een onjuiste opvatting.

Op Curaçao zou Van Walbeeck als directeur het bewind voeren, op de reis erheen evenwel was hij commandeur der flotille (Zie Nieuws Tijdingen 1634 No. 44). 
Creool. Op welke bevolkingsgroep is de naam creolen van toepassing? Deze vraag heeft wel eens aanleiding gegeven tot dispuut (zie o.a. West-Indische Gids XIII, blz. 399, 536, 572 e.v.).

Dat het woord creool, gebruikt met betrekking tot personen, meer te maken heeft (had) met ingeborenschap dan met ras of bloedsmenging, kan nog uit de volgende citaten blijken.

Corn. de Jong schreef in 1807 dat de hier (op St. Eustatius) gegeboren eilanders, evenals alle in de W.-I. geboren blanken, creolen genoemd werden (wanneer iemand voor een blanke gold zegt de auteur der Reize naar de Caraibische eilanden er niet bij).

Van Paddenburgh vertelt in zijn beschrijving van Curaçao (1819) dat vooral de blanke creolen Papiamentoe spraken; creolen en creolinnen vormden de plaatselijke beau monde. Waren alle creolen blank of waren er ook niet-blanke creolen?

Ds. Bosch (1829) ontmoette twee zuiver blanke Arubaansche creolen. De toevoeging zuiver geeft den indruk dat er creolen waren in graden.

Teenstra (De Negerslaven, 1842) zegt dat in Suriname, bij verdere vermenging met blanken, de kinderen der kleurlingen ten slotte blanke creolen werden genoemd.

Le Moniteur des Indes Orientales et Occidentales (1846/47) geeft een bepaling betreffende blanke creolen op de Nederlandsche Antillen: in de kolonie geboren kinderen van blanke vaders en moeders. Daarop echter volgt een opmerking aangaande de kleurlingen, welke overeenkomt met die welke Teenstra (zie boven) maakte ten aanzien van de Surinaamsche kleurlingen.

Dat men in de Ned. Westindische vastelandskoloniën gedurende den slaventijd het woord creool gebruikte in de speciale beteekenis van in het land geboren slaaf, is bekend; de vrouw die op de plantage de kinderen der in het veld werkende slavinnen verzorgde (?) heette in Suriname kroro mama (Enc. voor Ned. West-Indië). $\mathrm{Na}$ de emancipatie ging in Suriname de naam creool over op de gekleurde inheemsche arbeiders en kleine landbouwers, in tegenstelling met de immigranten uit Azië. Riko (Ons rijk Suriname, 1883) klaagt dat er voor de creolen zooveel minder wordt gedaan dan voor de immigranten; hij heeft het verder over creolen en vaste (inheemsche) arbeiders op de plantages.

Ober (Guide to the West-Indies) spreekt over „native and cre„ole Africans" op Trinidad in den slaventijd.

In een zeer recent werk, The European nations in the West Indies, 1493-1688, van Arthur Percival Newton (The pioneer histories) lezen wij dat de creolen op de Westindische eilanden 
meer gemengd van bloed waren dan de oorspronkelijke Spaansche immigranten. N. vermoedt dat het verdwijnen der Indianen op die eilanden het gevolg was van absorbeering door de creolen; na 1530 , zegt hij, konden bij indiaansche vrouwen verwekte kinderen gemakkelijk gelegitimeerd worden.

De vertaler van het werk van Père Labat (1725) gebruikte het woord creollen of creollers en noemt dan de witte - die op de eilanden geboren waren - en de kinderen der negers in de nieuwe wereld.

In Spaansche stukken van het begin der $17 \mathrm{e}$ eeuw wordt de omschrijving „criollos de las Indias” gebruikt, ook voor kleurlingen.

Van de toepassing van het woord creool op zaken kunnen eveneens nog meer voorbeelden worden aangehaald. In Venezuela heet inlandsch suikerriet caña criolla (Enciclopedia universal ilustrada Europeo-Americana); Van Dissel vertelt in zijn opmerkingen over Curaçao (31 Dec. 1867, Bijdr. Kon. Inst. v. d. taal-, land- en volkenk. v. Ned.-Indië) dat aldaar de nevenaren der afgesneden maisstokken kreolen werden genoemd; wie in Suriname geweest is, heeft daar creool-soda gedronken.

Hesseling (Het Negerhollands der Deensche Antillen) vertaalt creool eenvoudig met inheemsch; Van Dissel schreef over Papiamentsch of kreoolsch. Inderdaad, het is niet zoozeer de etymologie waar het op aankomt (in dit geval ook tamelijk onzeker), dan wel op de beteekenis, welke in verschillende tijden en op verschillende plaatsen aan het woord gehecht is.

Woorden waarvan de beteekenis veranderd is, of welke niet overal dezelfde beteekenis hebben, zijn er zoovele. Men denke aan: Arabier, Askari, cimarrón (maron, marodeur), Gringo, Indiaan, Kaffer, Koelie, Lascaar, Makamba, mameluco (Mammeluk), Marraan, Slaaf, Yankee, om ons maar tot personennamen te bepalen. Het Spaansch is overigens ook rijk aan zaaknamen met veel verschillende beteekenissen; men denke aan asiento en corral, om er maar enkele te noemen.

Curaçao (naam). Tot welke resultaten men kan komen, wanneer men op grond van klankovereenkomst een plaatsnaam wil verklaren, bewijst de aardigheid van den cura asado (gebraden priester), naar wiens onzalig maar volkomen legendarisch uiteinde het eiland genoemd zou zijn. Van menscheneterij op onze Benedenwindsche eilanden is nooit iets aangeteekend, al zou Vespucci de bewoners als dierlijk en onwetend hebben beschreven. 
Ook is het niet duidelijk, waarom de naam Curaçao, zooals anderen meenen, van Portugeeschen oorsprong zou zijn. Dat met het Spaansche woord corazón (hart) het Portugeesche coraçao overeenkomt zegt immers niets; Portugal heeft nooit iets met Curaçao te maken gehad.

Het Portugeesch-Amerikaansche gebied was Brazilië en nu is het wel eigenaardig, dat in The Captivity of Hans Stade of Hesse in A. D. 1547-1555 (Hackluyt Society, 1847, LI) de bewerker van de Braziliaansche kalkoenen spreekt als van de „Curassow „family.” Bedoeld werd de gladsnavelhokko (Crax alector L), maar dat de naam van ons eiland iets met dezen vogel uit te staan zou hebben, is ook al weder niet aannemelijk.

Dampier, William, die in 1681 Bonaire bezocht en een beschrijving van het eiland gaf (P.A. Euwens, Neerlandia, December 1907, Bonairenummer), wordt in de Dictionary of National Biography beschreven als „buccaneer, pirate, circumnavigator, captain of the navy and hydrographer". Hij leefde 1652-1715, was een goed schrijver en waarnemer, maar een middelmatig bevelhebber; er is aangaande hem veel litteratuur.

Doncker. Jan. Er is in de litteratuur strijd gevoerd over de integriteit van dezen Curaçaoschen directeur, in verband met de nogal zonderlinge gedragingen der Franschen in 1673 (zie Amelunxen).

De Baas wist bij zijn komst niet dat Otterinck overleden was; laatstgenoemde en Doncker waren geen onbekenden voor den Franschen gouverneur. In 1672 immers had De B. aan Colbert geschreven dat hij reeds van St. Christophe met den koopman „Douckre" en met den directeur Otterinck had gecorrespondeerd, omdat hij op de hoogte wilde komen van de prijzen der verschillende producten (zie Mims). Doncker, die ook op de andere eilanden geweest was en er zaken had gedaan, was allicht persoonlijk aan De B. bekend.

Het zou dus niet zoo vreemd zijn geweest, wanneer men het met elkaar op een accoordje had gegooid. De bestuurders ter plaatse moesten wel eens wijzer zijn dan de regeeringspersonen in Europa.

Zie De Baas.

Doop (aan boord). Het „doopen” van nieuwelingen op Oostindische reizen, bij het passeeren der linie, is meer algemeen be- 
kend, dan de overeenkomstige „plechtigheid” bij verschillende gelegenheden op reizen naar de West; allicht echter is deze laatste van ouder datum.

Bontekoe, die in 1619 de linie passeerde (voor hem zelf was dit de eerste keer) zegt in zijn journaal niets van eenige ceremonie. Exquemelin echter, die 1666 naar Tortuga uitvoer, geeft een omstandig verhaal van de doopplechtigheden, bij Hollanders en bij Franschen, bij het passeeren door het „Ras de Fonteneau” (bocht van Frankrijk) en vóór de „Barlingos” (klippen aan de Portugeesche kust), waarbij wijn wordt uitgedeeld, of geld geofferd, om later wijn voor het volk te koopen; het gebruik zou volgens sommigen op een ordonnantie van Karel V steunen. Bij het passeeren van den keerkring werd, volgens Fransch gebruik, wederom gedoopt.

Aan boord van 's Lands schip van oorlog Mars (de Jong, Reize naar de Caraibische Zee, 1780 - 1781) werd bij het voorbijzeilen der „Barlinges” het „valgeld” (afkoop door de nieuwelingen van het vallen van de ra, waar Exquemelin over schreef) opgehaald, om er op Madera wijn voor te koopen.

Esopus. Hamelberg vertelt dat Stuyvesant (in 1660) eenige Esopusindianen naar Curaçao verbande, maar laat het aan den lezer over het raadsel op te lossen van het verband tusschen Noordamerikaansche Indianen en een Griekschen fabeldichter.

Brodhead noemt de etymologie twijfelachtig, maar meent dat het woord afkomstig is van Seepus=rivier, eerst tot sopus, daarna tot esopus verbasterd. De Esopuskreek was destijds een belangrijke waterweg en thans draagt een rak of kil van de Hudsonrivier nog den naam Esopus (Dr. F. C. Wieder, De stichting van New York, Linschoten Vereeniging, 1925).

Kingston, hoofdplaats van Ulster County, Staat New York ( \pm 30.000 inwoners), ligt dáár waar in 1658 de Nederlandsche kolonisten het dorp Wiltwyck vestigden in het Esopusgebied, waarvan al het land in 1660 door de Indianen aan de Hollanders werd afgestaan. De geheele streek heette toen allang ook wel Wiltwyck en de Nederlandsche kolonisten moeten reeds vroeg in de 17e eeuw aan de monding der kreek een redoute hebben aangelegd. Het Esopusgebied was sedert 1660, ingevolge den wensch der Compagnie, een afzonderlijk rechtsgebied en Stuyvesant installeerde er in 1661, waarschijnlijk tegen zijn zin, schout en schepenen.

De verhouding tusschen kolonisten en inboorlingen was aan- 
vankelijk zeer goed, maar sedert 1655 is met de Indianenstammen van den Esopus herhaaldelijk oorlog gevoerd; het vredesverdrag van 1664 was de laatste overeenkomst. door "stiffnecked Peter” met de ,wilden" gesloten.

Voor de geschiedenis van Esopus of Wiltwyck in den Hollandschen tijd, van 1616 tot het verlies van Nieuw-Nederland, in den tweeden Engelschen oorlog, zie Brodhead's History of the State of New York, Ie deel.

Farine, in 1779 op St. Eustatius aangevoerd van Martinique, in vaatjes (W. R. Menkman, West-Indische Gids, XIV, 390).

Dit zal wel cassavestijfsel zijn geweest, dus wat men op Curaçao op zijn Spaansch goma noemt (P. L. Simmonds „The commercial products of the vegetable Kingdom) en in Suriname gomma.

Flamenco, niet flamengo (verg. Dr. F. W. Stapel, Maandblad Oost en West, Mei 1934, Curacaonummer).

Nederlanders werden door de Spanjaarden Flamencos genoemd. Tegenwoordig nog heet Hollandsche kaas in Spaansch Amerika queso flamenco.

Flibustiers (filibusteros). Vicomte de Motey (Guillaume d'Orange) schrijft dat een der twee schepen, waarmede in Februari 1628 een honderdvijftigtal Fransche kolonisten naar St. Christophe vertrokken, , un flibot” was, „sorte de flûte Hollandaise à „deux mâts, du port de cent tonneaux environ, carène renflée" (onder de waterlijn buikvormig), ,,arrière rond et haut".

In de Enciclopedia universal ilustrada Europeo-Americana vinden wij: „Flibote=filibote. Embarcación ligera y rápida // „Embarcación holandesa, de dos palos y mucha obra muerta" (veel bovenbouw).

Kesler (West-Indische Gids X, 67) vermeldt een Fransch zeeroover in 1526 in Brazilië en een ander in 1537 in de Caraibische Zee; Baralt (Resúmen de la historia de Venezuela) spreekt van flibustiers en boekaniers, die reeds in het midden der zestiende eeuw de Spaansche retourvloten uit Amerika aantastten.

Henri Malot ten slotte (Corsaires et Flibustiers) doet het geheele verhaal der Fransche „course”, de geschiedenis van den corsaire of armateur particulier, sedert de lettre de représailles plaats gemaakt had voor de lettre de marque, of commission en guerre. 
Gedurende den langdurigen strijd tusschen Frans I en Karel V waren het de corsaires van den eerste die ter zee aan den handel der onderdanen van den laatste (waaronder de Nederlanders) afbreuk deden. Dan volgen de ondernemingen tegen de uit Amerika terugkeerende Spaansche galjoenen, welke men bij de Azoren of Kaap St. Vincent opwachtte en aan boord waarvan men ook de zeekaarten vond, dienstig voor de vaart naar de Antillen.

In 1522 en 1523 schuimt de Normandiër Jean Fleury de kusten van het Iberische schiereiland en van Afrika af, als représaille tegen Portugal. Frans I gaf kaperbrieven af, ook voor ondernemingen in Afrika en Zuid-Amerika.

Fransche kapers maakten de vaart voor Spaansche retourvloten onveilig van Kaap St. Vincent tot de Antillen en toen de vijandelijkheden in 1542, na een wapenstilstand, hervat werden, ageerden de corsaires op de kust van Venezuela en in de golf van Mexico; in 1553 werd de kust van Santo Domingo geplunderd, in 1554 Santiago de Cuba, in 1555 Havana.

Kesler (zie boven) vertelt ons dat uit de sedert 1526 in Spanje van den handel geheven avería ook wel eens het convooi van en naar West-Indië werd betaald; Van Rees (Koloniale Politiek) dat in 1590 en 1591 in beslag genomen Nederlandsche schepen, met hunne bemanningen, gebruikt werden om de zilvervloten van Terceira te begeleiden.

Aan de geschiedenis der zeventiende eeuwsche vrijbuiterij in de Caraibische Zee was derhalve een langdurige periode voorafgegaan van particulieren zeeoorlog, in de Europeesche wateren aangevangen en steeds verder Westwaarts voortgezet.

Exquemelin noemt de Fransche en Engelsche vrijbuiters die geen tehuis in Europa meer hadden, maar wel steunpunten in West-Indië - zeeroovers, „alsoo sy van geen Potentaten ge„stut werden”. Met dat al werd er van de hulp dezer vrijbuiters gebruik gemaakt tegen den vijand, wanneer de „potentaten” in Europa met elkander in oorlog waren .De Engelsche expedities van 1665 en 1666 tegen de Nederlandsche eilanden en de Fransche "rodomontade" van 1673 waren vrijbuitersexpedities, al werd dan ook de eerste door den luitenant-gouverneur van Jamaica, de laatste door den gouverneur der Fransche Antillen aangevoerd; d'Estrées had in 1678 vrijbuiters onder zijn bevelen en Cassard (1712/1713), zelf een kaper, versterkte in West-Indië zijn macht met Fransche vrijbuiters (Marc. Elder, Jacques Cassard).

Individueele Nederlandsche (Zeeuwsche) kapers worden af en toe in de geschiedenis onzer Antillen genoemd (Pieter Marcus, 
Gerard Bogaert); tot de „brethern of the sea” echter hebben ook Nederlanders behoort. De ook in de geschiedenis van Tobago en Curaçao bekende Reining was een metgezel van Morgan geweest; Exquemelin noemt Mansveldt en kapitein Rok, Newton (European nations in the W.I.) maakt melding van Lourens de Graaf en Nikolaas van Hoorn.

Graaff, Johannes de, commandeur van St. Eustatius (17751781). Colenbrander (De Patriottentijd) noemt hem abusievelijk Van der Graaff.

Blok (Geschiedenis van het Nederlandsche Volk, VI, 320, zie ook het vierdeelige werk, III, 537) noemt Joh. de Graaff energiek; de geleerde schrijver acht dus de commandeur van St. Eustatius denzelfden lof waardig welken hij elders aan den oud-gouverneur van Ceylon W. J. Van der Graaff toezwaait. Ook Van Grol (Maandblad Oost en West, Curaçaonummer, Mei 1934, De Generaliteits Ambachten) noemt Johannes de Graaff een energiek gouverneur. (Zie eveneens Grondpolitiek I).

Men vraagt zich toch wel even af, wat deze laatste gedurende zijn zesjarig „commandement” eigenlijk voor energieks verricht heeft.

Wanneer Bisschop Grevelink de kwestie der begunstiging van zeeroovers onder Zuidamerikaansche vlaggen op onze Bovenwindsche eilanden behandelt, zegt hij dat Van Spengler (de gouverneur W. A. van Spengler) herhaaldelijk door de Regeering in Nederland gewezen was op de ontevredenheid in Engeland, maar dat hij slechts maatregelen had genomen à la die van De Graaff van 1778 .

Grand, Pierre le. Guillaume-Thomas Raynal gaf in 1781 zijn beroemde Histoire philosophique et politique des etablissemens et du commerce des Européens dans les deux Indes uit. In deel V (blz. 171) noemt hij onder de stoutmoedge daden der flibustiers het enteren van een Spaansch vice-admiraalsschip door Pierre le Grand van Dieppe.

Later verscheen, naar het werk van den abt Raynal, de Précis de l'Histoire philosophique et politique des Deux Indes en daarvan werd in 1784 door M. Schalekamp te Amsterdam een Nederlandsche vertaling uitgegeven: Tafereel van de bezittingen en den koophandel der Europeanen in de beide Indiën.

Hamelberg (De Nederlanders op de West-Indische eilanden) haalt het Tafereel aan (zonder den naam Raynal te noemen) 
en identificeert blijkbaar (ten onrechte naar alle waarschijnlijkheid) den flibustier Le Grand met den majoor in dienst der WestIndische Compagnie, die in 1634 Van Walbeeck naar Curaçao vergezelde.

Wanneer wij bij Exquemelin, die in 1679 schreef, lezen dat de eerste zeeroover van Tortuga een zekere Pieter de Groot van Dieppe was, die in 1602 met een equipage van slechts 28 man een Spaanschen vice-admiraal aantastte („bij Cabo del Fibrum kaap Tiburon - aen de West-hoeck van het Eylandt Espagni„ola"), dan hebben wij waarschijnlijk met het origineel te maken van het verhaal dat via Raynal bij Hamelberg terecht gekomen is.

\section{Hamilton, Sir Edward. Zie Hermione.}

Hermione. Wanneer Carel Brensa (West-Indië; Beschouwingen van een tourist) over de geschiedenis van het eiland Curaçao gaat mijmeren, dan trekt ook de muiterij van de Hermione aan zijn geestesoog voorbij. Die muiterij heeft echter niet op Curaçao - of in de Curaçaosche wateren - plaats gehad en geen enkel geschiedschrijver heeft het feit zich dáár laten afspelen.

Volgens Amelunxen viel de muiterij voor in het begin van 1796 en hernam Captain Hamilton het schip ter reede van Puerto Cabello (wanneer?) bij verrassing, terwijl de 400 man sterke equipage de rozekrans bad, onder welke devote bezigheid zij den vijand niet had hooren of zien naderen.

De Engelsche lezing (Traill \& Mann, The Building of Britain and the Empire en Dictionary of National biography) is eenigszins anders.

De muiterij had plaats op 22 Septersber 1797, in de buurt van Porto Rico; captain Pigot en 9 zijner officieren, waaronder een jeugdig adelborst, werden vermoord, de muiters zetten koers naar La Guaira en leverden daar het schip aan den vijand uit. De Spanjaarden rustten de Hermione uit met 44 stukken en bijna 400 man.

Voor de Britsche marine was het een eerezaak het schip weder in handen te krijgen, maar toch duurde het tot 1799 voordat dit gelukte. In October van genoemd jaar werd captain Edward Hamilton met de Surprise van Jamaica naar Puerto Cabello gedirigeerd, om naar het fregat uit te kijken. Na een paar maanden gekruist te hebben, besloot $\mathrm{H}$. (wiens victualie uitgeput raakte, misschien ook zijn geduld) „to cut her out”. 
Ook in de geschiedenis onzer Bovenwindsche eilanden van de merkwaardige tweede helft der 18e eeuw zijn gevallen bekend van schepen die van de reede werden ,uytgesneden".

Dit uitsnijden nu van de Hermione had plaats in den nacht van 24 op 25 October 1799, na een scherp gevecht aan boord van het fregat, waarbij 119 Spanjaarden gedood en 97 gewond werden; de Engelschen, die het schip van uit de sloepen hadden geënterd, hadden 12 gewonden, waaronder Hamilton zelf, ernstig.

$H$. werd met eerbewijzen overstelpt; de Koning verhief hem in den adelstand, Jamaica schonk hem een kostbare eeredegen, Londen bood hem het eereburgerschap aan.

Het bezoek aan Curaçao van de Magicienne, captain Rickert, zal dus wel begin 1798 hebben plaatsgehad, dat van Hamilton aan Aruba - waarbij hij den Curaçaoenaar Bolwig als loods aan boord zou hebben gehad, later schipper bij Kikkert op de Ceres in 1799, maar niet in Augustus, zooals Ds. Bosch vertelt. Het was bij deze middernachtelijke rencontre dat de kommandeur Specht (Borchard, die in 1792 aan het bewind was gekomen?) met schroot liet schieten, waardoor de bemanning der sloepen van het Engelsche oorlogsschip ernstige verliezen leed en o.a. de eerste officier sneuvelde. Brusse en Amelunxen laten dit gevecht een voor de Engelschen minder tragisch verloop hebben.

Brusse vermeldt twee Engelsche aanslagen op Aruba van omstreeks dezen tijd; Amelunxen vertelt dat na dien van Hamilton de batterijen eenigszins versterkt werden, zoodat een volgende aanval kon worden afgeslagen; Bosch daarentegen dat Specht al eerder een poging om schepen van de reede van Aruba weg te halen had verijdeld.

Aangaande het optreden der Engelschen op Aruba in 1805 en 1806 heeft, naar aangenomen mag worden, Mr. B. de Gaay Fortman in De Indische Gids van Januari 1931 alle licht ontstoken dat er te ontsteken viel.

Hopsack. Dit is een van die namen welke wij in verschillende koloniale gebieden terug vinden.

Het eilandje Goeree (Z.O. van Cabo Verde), waar een fortje lag van de Nederlanders (volgens Dapper sedert 1617) en dat in 1678 door d'Estrées werd veroverd, stond het laatst onder het bestuur van een gouverneur Hopsack (Newton, European nations in the West-Indies).

Een andere (of dezelfde) Hoppesack speelde op Curaçao een rol, als secretaris van den Raad onder van Liebergen (1679-1683). 
En was er in de $18 \mathrm{e}$ eeuw ook in Suriname niet een Hobbesack?

Hood, Samuel. Rodney's voorhoede in 1781 gecommandeerd door den schout bij nacht Sir Samuel Hood (W. R. Menkman, West-Indische Gids XV, 365).

Zoover was Hood destijds nog niet; hij was zelfs bij de vermeestering van Suriname en de andere Nederlandsche vastelandskoloniën in de West in 1804 nog de commodore S. Hood.

De Dictionary of National Biography geeft zijn verdere carrière als volgt: 1807 rear admiral, 1809 baronet ,1811 vice-admiral.

Joden. De in 1652 verleende privileges aan de Joden die zich op Curaçao gingen vestigen, zouden het eerste charter hebben gevormd waarbij aan Israëlieten in de nieuwe wereld godsdienstvrijheid werd gewaarborgd (Gedenkboek Nederland-Curaçao 1634-1934, pag. 69).

De godsdienstvrijheid echter welke èn aan Joden èn aan Roomsch-Katholieken in West-Indië werd toegekend, is van ouderen datum; zij is vastgelegd in de Ordre van Regieringe soo van Policie als Justitie, in de Plaetsen verovert ende te veroveren in West-Indiën, van 13 October 1629 (Groot Placaatboek.

Misschien is voor de geschiedenis der Joden op Curaçao nog van belang wat Oudschans Dentz in de W. I. Gids XII, 591, 592, mededeelde aangaande het Engelsche privilege (van 1654), dat echter waarschijnlijker een vertaling van het Nederlandsche van 1657 zou zijn geweest en van den brief aan Cromwell van 8 Maart 1657; er is hier sprake van emigratie naar een plaats tusschen Suriname en Cartagena. Leghorn noemen wij in het Hollandsch Livorno en het ging dus om Joden uit Italië.

Kapitein. Euwens heeft eens gesproken over kapitein Van Walbeeck (West-Indische Gids, X, 103) en anderen hebben dat ook wel gedaan. De carrière evenwel welke Van Walbeeck in 1634 reeds achter den rug had en de positie waarin hij naar Curaçao uitvoer, sluiten de mogelijkheid uit dat hij gedurende den overtocht de functie van algemeen leider der expeditie zou hebben moeten combineeren met die van bevelhebber over een der schepen, wat bovendien volkomen in strijd zou zijn geweest met de toenmalige tradities.

Het is ook erg twijfelachtig of onze Curaçaosche held ooit vroeger scheepsbevelhebber (d.w.z. bevelhebber over één schip) 
geweest was; daarvan althans is niets bekend. Zijn vice-commandeurschap en commandeurschap, later zelfs admiraalschap, van 1629 en 1630, behoeven er geenszins op te wijzen dat hij een oud-scheepskapitein zou zijn geweest.

Het verschil tusschen koopvaardij- en oorlogsonderneming sprak zich ook in de titels der bevelhebbers uit. De eerste schipvaart naar Oost-Indië werd in 1595 ondernomen met vier schepen, ieder onder een schipper; Cornelis de Houtman ging mede als oppercommies. Jacob van Heemskerck (de latere admiraal der Staatsche vloot) en Jan Corn. Rijp (de latere commandeur over twee commissievaarders) maakten als schippers Barent's reis naar het Noorden van 1596-1597 mede. Bontekoe voer in 1618 „voor schipper" naar Indië, op een vaartuig met ruim 200 man equipage; zijn zelfstandigheid tegenover den „koopman” Heyn Rol was niet altijd heel groot. In Indië aangekomen werd Bontekoe door den ,generael” J. P. Coen met den titel schipper aangesproken. Toen Bontekoe in 1625 thuisvoer was hij schipper op de Hollandia, tezamen met twee andere schepen gesteld onder den commandeur Reyersz.; kort voor binnenkomst stierf op de Hollandia de , capiteyn",maar dat was een officier over de soldaten. Van twee convoyers, welke op de uit Indië te verwachten schepen kruisten, vermeldt Bontekoe de namen der capiteyns, maar convoyers waren schepen van oorlog.

De Ruyter heeft, voordat hij in staatsdienst trad, als schipper gevaren, maar ook als kapitein, op een der kruisers n.l. van de gebr. Lampsins (zie P. J. Blok, Michiel Adriaansz. de Ruyter), zooals ook Jan Gideon en Abr.Crijnsz., de bevelhebbers van eenige jaren vroeger over de Nieuwe Geuzen, den titel van kapitein voerden. Wie het gezag voerde op een schip dat tegen Duinkerkers of Biscayers ageerde, of op Brazilië avontureerde (Dirck Jansz. Goethals, Harmen Cleuter, Cleynsorch, Rombout van der Perre, Thomas Six) was kapitein , of capiteyn te Water en notoire zeeroovers, als Claes Compaen en de beide Dansers, zullen zich wel niet met een minder krijgshaftigen titel tevreden hebben gesteld, ook al hadden zij geen commissies, die enkelen echter wèl hadden.

De eerste drie schepen, welke voor de Compagnie uit de West thuiskwamen, de Grijpende Arent, midden December 1623, de Liefde en d'Orangieboom, beide in Januari 1624, hadden zakenreizen gemaakt (zout en St. Martenshout) en de gezagvoerders waren de schippers Jan Jarichs van Staveren, Idzert Jarichs en Symon Symonsz. 
Merkwaardig is echter dat de bevelhebbers van een tiental schepen, zoo Compagnies- als gehuurde schepen, die in 1623 onder Jacob Willekens en Piet Heyn uitvoeren voor de expeditie naar San Salvador in Brazilië, door Van Wassenaer (Historisch Verhael) schippers werden genoemd; een koopvaardijman kon blijkbaar aan een militaire expeditie deelnemen, zonder commissie als kapitein ter zee. Gelijk schipper Bontekoe onder Reyersz. van der Gou zich bij verschillende krijgsbedrijven betrokken zag. Stuurde men eenige schepen van Brazilië via West-Indië naar huis, onder een commandeur en een vice-commandeur, om onderweg op vijandelijke schepen jacht te maken, dan stond het schip dat geen vlaggeschip was onder bevel van een schipper (Joh. de Laet, Iaerlijck verhael, 267).

In de Oost- en Westindische voyagiën (bij Iost Hartgers, 1648) lezen wij dat een schipper, wegens een sterfgeval, als „Capiteyn „ende Schipper” op een ander schip werd overgeplaatst. Schipper ende capiteyn komt ook voor (bij De Laet).

Kayen, Kajen. Aangenomen mag worden, dat de Spanjaarden den naam cayo hebben gegeven aan een weinig boven water uitstekend eilandje (islote bajo) en dat de Engelschen dien naam hebben verbasterd tot Cay, daarna tot Key; achttiende eeuwsche Nederlanders vertaalden dan soms dat Key met sleutel (Zeeatlas van Keulen, Zoutsleutel voor Salt Key).

Wij vinden evenwel in Nederlandsche gegevens ook Kayen en Kajen. In de Statiaansche schepenlijsten van 1779 heeft de constabel van het fort Oranje een schip vermeld als aangekomen van Schiltpatkayen, zeker niet vermoedende dat anderhalve eeuw later iemand zich het hoofd zou moeten breken met de vraag waar die plaats van herkomst gezocht moet worden (Dry Tortuga's, bij Tirion de Schildpadden genoemd?)

De bekende Zeeuwsche avonturier Reining (Zeer aanmerkelijke Reysen Gedaan door Jan Erasmus Reining, D. van der Sterre, med. doct. op Curaçao, Amsterdam 1691) ontvluchtte uit Fransche gevangenschap - na zijn exploit op Grenada - en ging in een boot van Isla Blanco, vóór den wind, naar de Dronkemans-Kajen, recht tegenover Curaçao. Welke eilandjes zou Dr. v.d. Sterre daarmede wel bedoeld hebben? Of met de „Zuyt„Kajen”, waar men proviand ging zoeken?

Ook de Franschen hebben hun cayes, o.a. Cayes, Les Cayes of Aux Cayes, aan de Zuidkust van Haiti.

Zie Salt Tortugas. 
Kraalzee. De zee ten Noorden van Curaçao wordt op de 18e eeuwsche kaart van Van Keulen de Kraalzee genoemd.

Men denkt onwillekeurig het eerst aan koraal (Sp. coral), van wege de vele koraalsteenen op onze Benedenwindsche eilanden, maar ook aan kraal (Sp. corral), voor omheinde ruimte; de $\mathrm{Ca}$ raibische Zee is rondom door een krans van eilanden afgesloten.

Corral aan de kust van Chili ligt aan een zeer besloten inham.

Mansfield was volgens Constant van Wessem, den bewerker van Exquemelin's Am. Zeeroovers, een Curaçaoenaar, genaamd Mansveldt. Hij zou in 1665 zijn gestorven, wat niet uitkomt.

Zie Morgan.

Mars. De groote en de kleine. De Jonge (Geschiedenis van het Nederl. Zeewezen) vertelt dat de kleine Mars (het Lands fregat) op 3 Februari 1781 ter reede van St. Eustatius kloekmoedigen tegenstand bood. Cornelius de Jong echter, die vier dagen later ter plaatse was en direct met zijn collega's contact kan hebben gehad, beweert dat Van Bylandt volgens onderlinge afspraak de laag heeft laten afvuren, alvorens de vlag te doen strijken; een schijngevecht dus, alleen om de eer te redden. Was dit dan misschien een kombuisverhaal?

De groote Mars (het Landsschip) was volgens Knappert (WestIndische Gids, XIV, 38, noot) slecht gebouwd. Dat aan de lijzijde de onderste batterij bij overhellend schip niet gebruikt kan worden, lijkt echter nog geen bewijs voor de slechte constructie van een $18 \mathrm{e}$ eeuwsch oorlogsschip.

Methodisme. Ds. Rauws (Curaçaonummer Maandblad Oost en West) zegt dat de grondslag der Methodistengemeente op St. Eustatius in 1786 gelegd werd door den vrijen neger Harry. Ook A. H. Bisschop Grevelink noemt parson of dominé Harry, die bij zijn wegvoering een vloek over het eiland zou hebben uitgesproken, een vrije neger, maar vertelt erbij dat hij als slaaf verkocht werd, een voorbeeld dus dat een eenmaal vrijverklaarde weder in den toestand van slavernij terug kon worden gebracht; ook de zwarte Surinaamsche Guides waren niet onherroepelijk vrij.

Aangaande Harry zie verder Knappert (Geschiedenis der Bovenwindsche Eilanden), die tevens de geschiedenis van het Methodisme op onze eilanden uitvoeriger behandelt (bezoeken Dr. Thomas Coke aan St. Eustatius 1787, 1789, 1790 en 1792, aan Saba 1789; prediking van het Methodisme op St. Maarten door den vrijen kleurling John Hodge in 1817). 
De Curaçaoshe Verslagen 1932 en 1933 bevatten eindelijk eenige gegevens aangaande de Methodisten- en Anglikaansche gemeenten op onze Bovenwindsche eilanden. In de rubriek Eeredienst der oudere Verslagen van Bestuur en Staat (Curaçao) werd over deze geloofsgemeenschappen gezwegen.

Middleton, David. G. B. Bosch (Reizen in West-Indië, 1829) en P. A. Euwens (Bonairenummer van Neerlandia, December 1907) vertellen van het bezoek dat deze Engelschman aan de later Nederlandsche - Benedenwindsche eilanden bracht in 1601 .

Het verhaal is in de Nederlandsche litteratuur verschenen door de uitgave van J. L. Gottfried's Zee- en landreizen (Ve deel, reizen der Engelschen, 1558/1696, P. van der Aa, 1706). Middleton's schip liep Bonaire voorbij, ankerde aan de W.-zijde van Curaçao en ging van daar naar Aruba, om water te laden.

De Dictionary of National Biography zegt van Middleton dat hij in kwaliteit van koopman en scheepsgezagvoerder veel succes had (vooral in Oost-Indië); hij maakte in 1601 als mede-bevelhebber een reis naar West-Indië en overleed in 1615.

Missie. Machado (El asalto a Curaçao) spreekt over la Compañia de Jesús.

De Societeit van Jezus heeft echter reeds in 1742 de missie op Curaçao opgegeven (Gedenkboek Nederland-Curaçao 1634-1934, pag. 142).

Zooals bekend is, berust de Curaçaosche missie bij de provincie der Paters Dominikanen in Nederland, reeds sedert 1868.

Morales-Morillo. Na den slag bij Carabobo (1821) ontruimden de Spaansche troepen de vaste kust, met uitzondering van Puerto Cabello. Een Spaansch generaal verscheen kort daarna op Curaçao, om gelden in te zamelen bij de Spaansche vluchtelingen en vivres te koopen voor de eenige overgebleven Spaansche vesting. Dezelfde generaal kwam later (in October van hetzelfde jaar) wederom op Curaçao en werd toen door de vergramde bevolking - er waren Curaçaosche schepen genomen door Spaansche kapers - lastig gevallen; het Bestuur herstelde de orde, maar Cantz'laar maakte den Spanjaard allerlei verwijten.

Corporaal (De internationaalrechtelijke betrekkingen tusschen Nederland en Venezuela) noemt dezen generaal Morillo, waarschijnlijk op grond van Curaçaosche berichten uit dien tijd. Amelunxen spreekt van generaal Morales. 
Het kan inderdaad onmogelijk de bekende, later tot graaf van Cartagena en markies de la Puerta verheven Pablo Morillo zijn geweest. Deze immers, die in 1814 naar Zuid-Amerika was gezonden, om den opstand te bedwingen en die zich vijf jaar lang in een vijandig land had staande gehouden, met een kleine krijgsmacht en zonder voldoenden steun uit het moederland, had kort na het sluiten van den zesmaandschen wapenstilstand - tractaat van Trujillo, 16 November 1820 - verlof gekregen om naar Spanje terug te keeren - waar hij verder in de politiek van het schiereiland een rol zou spelen - en was opgevolgd door Miguel de la Torre (Enciclopedia universal ilustrada Eurpeo-Americana). Degene die tweemaal op Curaçao is geweest, moet Torre's onderbevelhebber Morales zijn geweest.

De la Torre en Morales werden bij Carabobo door Bolívar en Páez verslagen.

Morgan. Hamelberg spreekt van den luitenant-gouverneur van Jamaica, die in 1665 met succes een aanslag pleegde op St. Eustatius en aldaar kwam te overlijden, als van een zeeroover, wat denken doet aan den bekenden buccaneer Henry Morgan. De colonel echter, die St. Eustatius veroverde, was Edward Morgan, een oom van Henry, welke laatste met de dochter van den eerste trouwde (d.w.z. later). Henry wordt het eerst genoemd als bevelhebber van een schip, wanneer de gouverneur van Jamaica, Sir Thomas Modyford, vroeg in 1666, den beruchten boekanier Edward Mansfield opdracht geeft om Curaçao aan te tasten, een onderneming welke, zooals bekend is, op niets uitliep (Dictionary of National Biography).

Knappert (West-Indische Gids XI, 355) denkt, in verband met het op St. Eustatius gebeurde van 1665, ook direct aan Morgan den neef - die er echter part noch deel aan had - en noemt hem John, naar het voorbeeld van A. O. Exquemelin (De Americaensche Zeeroovers), die echter den voornaam blijkbaar verkeerd geeft.

Nederlandsch. Wij beschikken over berichten van 1778 en 1780 - van twee verschillende zijden - aangaande de Nederlandsch-onkundigheid der blanken op de drie Bovenwindsche eilanden (W. R. Menkman, W. I. Gids XV, 107). De Jong (Reize naar de Car. Eil. 1780 en 1781) zegt dat op St. Eustatius vooral de vrouwen weinig Hollandsch kenden en ook hij verkeerde natuurlijk met de notabelen. 
Abr. de Veer rapporteerde in 1819 dat op St. Eustatius slechts zes personen Nederlandsch spraken (Dr. J. de Hullu, Bijdr. Taal-, Land- en Volkenkunde van N.-I. 1913); Cantz'laar schreef ongeveer te zelfder tijd dat er op St. Maarten niets anders dan Engelsch onderwezen werd en dat op Saba niemand Nederlandsch verstond (De Hullu, Indische Gids 1916).

Ds. Bosch, die de twee grootste der Bovenwindsche eilanden in 1816 bezocht, vertelt dat op St. Maarten de heerschende taal Engelsch was, maar dat het Hollandsch spreken aldaar, ook door de planters, hem meeviel.

Van den Bosch vond in 1828 de Engelsche taal op St. Eustatius en St. Maarten algemeen in gebruik; op laatstgenoemd eiland had hij geen enkele dame ontmoet die het Nederlandsch ook maar verstaan kon; de secretaris Beckers op St. Maarten kende aldaar acht personen die Nederlandsch spreken konden (Brieven van den Commissaris-generaal, Bijdr. en Meded. Hist. Genootsch. LI).

$M g r$. Niewindt. Een moedig voorvechter voor de afschaffing der slavernij noemt P. fr. M. J. Kösters O.P. den eersten apostolischen vicaris van Curaçao (Curaçaonummer Maandblad Oost en West).

Op 20 Februari 1849 schreef N. aan Baron van Wijkersloot, dat het Gouvernement aan de manumissies geen bezwaren in den weg mocht leggen, maar integendeel de emancipatie op alle mogelijke wijzen behoorde te bevorderen en op 8 Januari 1850, dat een plotselinge en algemeene emancipatie het grootste ongeluk voor de Kolonie zou zijn. En, voegde hij erbij, wanneer de slaven eens niet geëmancipeerd zouden worden, dan was de godsdienst het beste middel om hen in bedwang te houden en aan hun meester onderdanig te doen zijn.

Vurig abolitionistisch klinkt dit alles niet. Niewindt is opgekomen tegen den misstand dat oude en gebrekkige slaven door de meesters werden vrijgegeven, om ontslagen te zijn van de verplichting in hun onderhoud te voorzien; hij heeft er voor gestreden dat de missionarissen hen zouden mogen onderwijzen, dat zij ter kerk zouden mogen gaan en dat zij een huwelijk zouden mogen sluiten (Dahlhaus, Monseigneur Martinus Joannes Niewindt, 1924).

Eigenlijke voorvechters der abolitie heeft ons land niet opgeleverd, ook al noemden fatsoenlijke lieden op het laatst der $18 \mathrm{e}$ en in het begin der 19e eeuw den slavenhandel een schande der menschheid. Teenstra, die in 1842 zijn Negerslaven in de Kolonie Suriname uitgaf en in 1844 zijn adres tot de Tweec'e Kamer rich- 
te, zou misschien als een voorvechter van de afschaffing der slavernij kunnen gelden, maar dan alleen bij gebrek aan vuriger strijders.

Ogeron. Brusse (Curaçao en zijn bewoners, 1882) beweert dat Ogeron aan den tocht van De Baas in 1673 heeft deelgenomen. Het Omstandigh Verhael van de Fransche Rodomontade noemt hem echter niet.

Bertrand d'Ogeron de la Bouère verkreeg in 1665 het bewind over Tortuga, waar hij ernstige pogingen deed om van dit piratennest een landbouwkolonie te maken. In 1673 makte hij zich meester van verschillende havens van Spaansch Española en stichtte hij een Fransche kolonie te Samaná. Hij vertrok in 1674 naar Parijs, waar hij het volgende jaar overleed (Larousse).

Zie aangaande Ogeron ook Exquemelin en Newton.

Oranjegezindheid. In aanmerking genomen alles wat er in Patria te doen is geweest, met betrekking tot de opvolging van Prins Willem V in de waardigheden zijns vaders, waarin de EngelschFransche tegenstelling mede een factor van beteekenis was, zou het interessant zijn te weten, hoe men op onze Westindische eilanden, vooral op die waar de blanke bevolking uit verschillende nationaliteiten was samengesteld, wel tegenover de kwestie stond.

Welnu, op St. Eustatius was 8 Maart 1766, de dag waarop de stadhouder in Holland zijn achttienden verjaardag vierde en waarop hij het erfstadhouderschap aanvaardde, een groote feestdag; zelfs de slaven waren met oranje getooid. Een welgesteld inwoner, met een Franschen naam nog wel (François Sejourné), had zijn huis geilllumineerd (Maand. Nederl. Mercurius).

Papiamentoe. Wanneer is deze taal ontstaan en onder welke menschen, Indianen of negers?

Van Paddenburgh beweerde dat P. bij de komst der Nederlanders reeds bestond en daarna alleen maar veranderd is, maar hij geeft geen argumenten; waarschijnlijk lijkt zijn bewering niet.

Met het handjevol Indianen $( \pm 75)$ dat in Augustus 1634 op Curaçao achterbleef, zullen de Europeanen aanvankelijk wel nauw contact hebben gehad, omdat er voorloopig geen andere gekleurde werkkrachten aanwezig waren. Maar spraken die Indianen een taal welke als de oorsprong van het tegenwoordige Papiamentoe mag worden beschouwd?

Nergens elders in Spaansch-Amerika is een afzonderlijke kolo- 
niale taal ontstaan. Waarom zouden de Spanjaarden juist op de Benedenwindsche eilanden hun taal door de inboorlingen (tevens bekeerlingen )hebben laten verhaspelen? Ook al zouden de Indianen ,bedorven Spaansch" hebben gesproken en al zou het Papiamentoe indiaansche elementen bevatten (Van Paddenburgh), daardoor wordt dit laatste nog geen taal van indiaanschen oorsprong.

Exquemelin, die in 1669 Aruba bezocht, zegt dat dit eiland bewoond werd door "Indianen, die Spaansch spreecken" en dat Spaansch zal voor Morgan's lieden verstaanbaar zijn geweest, immers men dreef ruilhandel, schapen en geiten (versche proviand dus) tegen Europeesche manufacturen.

De gewoonte der blanken in de tropen om de verzorging hunner jonge kinderen aan inlandsche (d.i. - op Curaçao - Papiamentschsprekende) bedienden over te laten, lijkt een aannemelijke verklaring voor de groote plaats welke het Papiamentoe onder de inheemsche hoogere standen innam en nog steeds inneemt. Deze verklaring volgt zoowel uit het in 1819 door Van Paddenburgh als uit het in 1934 door Henriquez (Curaçaonummer Natuur en Mensch) medegedeelde.

Volgens Ds. Bosch (1829) had het Nederlandsch sedert 1816 goede vorderingen gemaakt, maar had onze taal na 1824 geen kans meer, omdat de R.K. missionarissen uit de Nederlanden zich met zooveel ijver op het Papiamentoe toelegden.

Patienje. Waarom noemde men op Curaçao het stuk van acht een patienje?

Teenstra (De Nederlandsche West-Indische Eilanden) geeft als equivalent Patinko (Port.). Van Paddenburgh (Beschrijving van het eiland Curaçao, 1819) spreekt van Patmos, Patos of Patokos, Ds. Bosch (Reizen in West-Indië, 1829) vertaalt patienje met piaster.

Hobson-Jobson (Colloquial Anglo-Indian words and phrases) geeft Pataca of Patacoon van het Port. patàca of patação, oorspronkelijk afgeleid van een Arabisch woord, dat eenvoudig munt beteekent.

Pitselingo. Simon van Leeuwen (Batavia illustrada, 1685) vertelt dat de Zeeuwsche kapers tijdens den oorlog met Spanje voor Pitselingo werden gescholden. Prins (De vestiging der Marranen in Noord-Nederland in de XVIe eeuw, 1927) vertaalt dit Pitselingo vlot als Vlissinger, wat logisch lijkt.

De strijd welke hier te lande in 1931 gevoerd werd over dit 
„raadselachtige” woord (Euwens, West-Indische Gids, XIII, 337) zou eigenlijk weinig beteekenis hebben gehad, ware het niet dat er een massa interessante gegevens gemeengoed door geworden zijn.

Postzegels. De vraag is wel eens behandeld, of de Todd- en Jesurunzegels al dan niet Curaçaosche postzegels waren, in verband met de vlaggen, gevoerd door de schepen, waarmede de mails voor Europa naar St. Thomas vervoerd werden (Ned. Philatelisten-Bibliotheek $\mathrm{N}^{\circ} 1$; De Philatelist, 1 Mei 1929).

Volgens de Koloniale Verslagen werd op Curaçao alleen in 1869 en 1870 voor het vervoer der mails naar St. Thomas van den Jesurun-stoomvaartdienst gebruik gemaakt en was het s/s Honfleur (Zie ook De Curaçaosche Courant, scheepvaartberichten 22 Januari 1875) een Nederlandsch schip. Dat de voorganger van dit paketstoomschip - de Robert Todd - op Curaçao zou hebben gevaren blijkt niet.

Prijsvraag. In 1842 schreef het Zeeuwsch Genootschap der Wetenschappen een prijsvraag uit over de geschiedenis der Zeeuwsche volkplantingen in Amerika (Zie Bijdragen tot de kennis der Nederlandsche en Vreemde Koloniën, bijzonder betrekkelijk de vrijlating der slaven, 1844). Het antwoord moest vóór 1 October 1843 ingediend worden.

Voor zoover valt na te gaan, is er nimmer een antwoord binnengekomen (inlichting Mr. A. Meerkamp van Embden, Secretaris van het Genootschap).

Quakers op Curaçao. De la Porte vond quakers op Curaçao, Raveneau de Lussan, meer dan een halve eeuw vroeger, croates, die er toen zelfs een eigen ,tempel” zouden hebben.

De Lussan's croates werden in de uitgave zijner mémoires van 1775 cuacres en Euwens (West-Ind. Gids XVI, 226) meent dat met croates en cuacres slechts Lutheranen bedoeld kunnen zijn. Merkwaardig is, dat in 1685 zoowel het bezoek van den Franschen kaper plaats had, als het vertrek van den Lutherschen predikant (Eldermans, Gedenkboek Nederland-Curaçao 1634-1934, 193).

Hoe zijn de croates veranderd in cuacres? Heeft de bewerker der latere uitgave van de mémoires misschien den Voyageur François geraadpleegd? Maar hoe was deze laatste aan zijn quakers gekomen?

De aanwezigheid op Curaçao van Engelsche quakers lijkt 
eigenlijk iets aannemelijker dan die van Hongaarsche protestanten. Ook op Tortola zouden quakers gevestigd geweest zijn (Enciclopedia Europeo-Americana).

Raders, R. F. van, werd bij K. B. van 25 October 1835 in den Nederlandschen adel ingelijfd, met den titel baron, bij eerstgeboorte.

Zijn oudere broeder, W. J. L. van Raders, had dus geen recht op den titel; toch schreef Bisschop Grevelink in 1846 van den Kommandeur van St. Eustatius (1826-1836) als van W. J. L. Baron van Raders.

Reizen. Teenstra (Ned. W. I. Eilanden) achtte het blijkbaar van algemeene bekendheid dat reeds in 1523 een Zeewsch schip de nieuwe wereld zou hebben bezocht. Anderen, die hem naschreven, hebben niet de moeite gedaan naar een bron te zoeken; in ieder geval echter heeft Teenstra niet geschreven dat dit Zeeuwsche schip op Curaçao zou zijn geweest (verg. W. G. de Bas, Marineblad Juli 1934).

Het verhaal van den Bretagner Jean-Remi Perrin, die in 1602 naar Brazilië voer, maar den koers kwijt raakte, op Curaçao aanlandde en daar 12 jaar onder de wilden leefde, is afkomstig van den Abt De la Porte (Le voyageur François), die het vertelt in zijn 136en brief (12e deel) gedagteekend Cartagena 12 Maart 1751. De la P. had toen juist Curaçao bezocht (waar hij veel suikerplantages had ontdekt, alsmede veel quakers onder de bevolking) en het verhaal van Perrin was hem gedaan door twee Hollanders. Een Hollandsch schip, op weg naar Guiana, zou op $\mathrm{Cu}-$ raçao verzeild zijn geraakt en de Indianen zouden den schipper gebracht hebben naar de hut van Perrin, waarin deze, zijn einde voelende naderen, het relaas van zijn verblijf op den wand zou hebben geboekstaafd; ook de kleeren en eenige andere zaken, aan P. toebehoord hebbende, zouden door de Indianen vertoond zijn.

Men mag aannemen dat Curaçao in het begin der 17e eeuw geen onafhankelijke, wilde bevolking had en dat er althans eenig Spaansch gezag was, hetgeen de geschiedenis van Perrin al reeds tot een fabel zou maken; De la Porte zegt trouwens dat hij op een Engelsch eiland in West-Indië een volmaakt eensluidend verhaal had gehoord. Dat de Hollandsche kapitein eenigen tijd op het eiland zou zijn gebleven, om van de gesteldheid in zijn vaderland verslag te kunnen doen en er zelfs een versterking zou heb- 
ben gebouwd, zooals de beide Hollanders den abt vertelden, kan natuurlijk gerust als een aperte onwaarheid worden gebrandmerkt.

Teenstra intusschen heeft het verhaal overgenomen en hij laat het zelfs in het midden der $16 \mathrm{e}$ eeuw spelen; ook anderen hebben ò Teenstra nageschreven, of het relaas van De la Porte als zoodanig overgenomen.

Salempouris. Een soort sits of bedrukt katoen, dat de O. I. Compagnie in Europa aanvoerde en dat ook zijn weg vond naar de West.

Salem, een stad en ook een district in Zuidelijk Voor-Indië (presidentschap Madras), waar een zeer oude weefindustrie gevestigd is. De producten dier industrie waren reeds vóór 1600 in Europa bekend (Hobson-Jobson, Colloquial Anglo-Indian). Jan Huygen van Linschoten (Itinerario) noemt Salampouris een wit lijnwaad.

Salt Tortugas. (W. R. Menkman, West-Indische Gids, XIV, 371/372). West van Orchilla ligt ook nog een Salt Cay. Tortugas noemden de Spanjaarden ook de weinig boven water uitstekende eilandjes, welke er uitzien als de ruggen van schildpadden; men behoeft dus niet juist te denken aan eilanden waar schildpadden gevonden werden.

Zie Kayen. Kajen.

Scharloo. Van Paddenburgh (1819) schreef Charlois en volgde dus de spelling van den naam van het plaatsje bij Rotterdam, dat dien naam dankt aan Karel van Bourgondië, graaf van Charolois (Te Lintum, Rotterdam in den loop der eeuwen).

Misschien mag hieruit worden afgeleid, dat Scharloo op Curaçao oorspronkelijk ook Charlois heeft geheeten, omdat het als voorstad aan Charlois bij Rotterdam herinnerde.

Er bestaat nog een Scharloo in Alkmaar en het Alkmaarsche adresboek teekent erbij aan dat het woord arme, magere zandgrond beduidt. Volgens een deskundig advies echter is deze naam er een als zoovele andere in ons land, waarin lo of loo beteekent hoogere plek (zand) grond, te midden van, of grenzend aan moerassen, of lagere landen.

Ten slotte heeft schaar of schoor ook nog de beteekenis van (meer-) oever.

Alles bij elkaar genomen kan Scharloo op Curaçao zoowel aan Alkmaar als aan Rotterdam herinneren (men denke aan het Waaigat). 
Scheepstypen. In Nieuwe reizen naar de Fransche eilanden van Amerika, de in 1725 te Amsterdam bij Balthasar Lakeman verschenen Nederlandsche vertaling (door W. C. Dyks) van het werk van Père Labat, komen teekeningen voor van drie $17 \mathrm{e}$ en $18 \mathrm{e}$ eeuwsche schepen, in West-Indië in gebruik, te weten een bark, een brigantijn en een korvet.

De bark (éénmast vaartuig), Spaansch balandra, Engelsch sloop, wordt thans nog op onze eilanden bark of balander genoemd.

Verder geeft Labat beschrijvingen van een kits (tweemast vaartuig), een pirogue (Spaansch piragua) en een canoa, welke laatste naam tegenwoordig nog gegeven wordt aan een klein inlandsch vaartuig voor de vischvangst.

In den brief van John Trottman (W. R. Menkman, West-Ind. Gids XV, 357) werd gesproken over een in November 1776 ter reede van St. Eustatius liggende Amerikaansche „pilot boat”. Men behoeft zich niet af te vragen wat Amerikaansche loodsen op St. Eustatius te maken hadden, want het gold hier geen loodsboot, doch een soort schoener.

In het eerste nummer immers der Curaçao Gazette and commercial advertiser (11 December 1812) wordt geadverteerd een snelzeilende „Pilot Boat Schooner”, gereed om te vertrekken naar St. Thomas. Nog in 1850 vinden wij de ,sharp-pointed New "York pilot boat" vermeld (Herman Melville, Moby Dick or the white whale, Chapter LX).

Met het vaartuig dat in het Nederlandsch een kotter heet heeft wel de Curaçaosche balander, of bark, maar niet de op de kust van Venezuela varende schoener overeenkomst (verg. Dr. M. A. van Weel, West-Ind. Gids XV, 153).

Over de geschiedenis der Noordnederlandsche fluitschepen zie voordracht Dr. J. H. Kernkamp voor het Utr. studentencorps, 31 Januari 1925.

Zie Caracas en Flibustiers.

Schottegat. Eenige jaren geleden stelde een Hollandsche hoofdambtenaar op Curaçao bij een openbare plechtigheid aan een lid der familie Schotborgh de vraag, of de naam van deze laatste iets met het Schottegat te maken had. Het antwoord luidden - natuurlijk - ontkennend.

Elke baai, inham of bocht heette in de 17e eeuw een gat en, wanneer het niet aan de eischen van den zeeman voldeed, een „onbequaem gat”. Het Schottegat was daarentegen een gat waar men beschut lag, een afgesloten baai. 
Op de kaart van Van Keulen komt een Schottegat (met ankerplaats) voor in de St. Annabaai, tegenover de plaats waar het Gouvernementshuis staat.

Schout bij nacht. Willem Crull, Heer van Burgst, die in 1781, enkele dagen na vertrek van St. Eustatius, sneuvelde, was op 57 of 58 jarigen leeftijd tot s. b. n. bevorderd en had bij zijn dood zijn $60 \mathrm{e}$ jaar nog niet voltooid; Corn. de Jong maakte hem wat ouder (63 of 64) en zegt dat hij zeer anti-Engelsch was, doch van de Eng. taal slechts weinig verstond.

Volgens het verhaal der Reize naar de Caraibische Eilanden was destijds op de vloot vroedvrouw de spotnaam voor schout bij nacht.

Blok (M. Adr. de Ruyter) meent dat de eigenaardige titel schout bij nacht (Eng. rear admiral, Fr. contre-amiral) alleen bij de Hollandsche marine voorkomt. De Denen echter kenden, althans in de $18 \mathrm{e}$ eeuw, dien naam eveneens; natuurlijk van de Hollanders overgenomen (Westergaard, Danish West Indies).

De titel is ontstaan toen in sommige Nederlandsche steden een speciale schout voor den nachtdienst aangesteld werd. (Middelnederl. Woordenboek).

Slavenschepen. In het Algemeen Rijksarchief bevindt zich een bundel instructies, uitgegaan van het college der X van de WestIndische Compagnie, waaronder een fragment van een voorschrift aangaande de behandeling der negerslaven op de reis van de kust van Afrika naar de West; op dit fragment is de dagteekening 7 April 1682 aangebracht. Uit Hudig (de Scheepvaart op West-Afrika en West-Indië) krijgt men den indruk dat die voorschriften tot een eind in de 18 e eeuw nog altijd nageleefd werden.

Bekend is dat aan boord van de slavenschepen ochtend- en avondgebeden moesten worden gehouden en dat aan de schepelingen op zware straffen verboden was zich met de negerinnen „te vermengen".

Andere voorschriften echter waren niet minder interessant.

De schepen lagen in Afrika eenigen tijd - soms langen tijd „in lading" en dan moesten maatregelen genomen worden om te voorkomen dat de negers zouden ontsnappen, of het schip zouden afloopen; op de overtocht was daar natuurlijk weinig gevaar meer voor. Aan den anderen kant moesten de slaven gedurende het verblijf op de kust in een goede stemming worden gehouden, door kost van den wal te schaften, wat tevens de gevreesde scheurbuik voorloopig op een afstand hield. 
In Afrika sloeg men voor de reis limoensap, palmolie en „milies” (mielie of mais) in; de kost zou tijdens den overtocht echter hoofdzakelijk uit Europeesche voedingsmiddelen bestaan.

Tot „vermaak en divertissement” gingen twee trommels mede, alsook een stuk hout, palo de „taculo”(?), van welk laatste de negers kleine stukjes kregen, om zich te beschilderen, of als middel tegen hoofdpijn. De mielie, welke alleen als ziekenkost diende, werd tusschen steenen fijngewreven, met welken arbeid de vrouwen belast moesten worden, ,om deszelve des te frisscher en ge„zonder te houden". Drie maal per week werden beschuit, brandewijn, tabak en pijpen verstrekt.

Voor de toebereiding van het eten golden voorschriften, welke ten doel hadden een zuinig verbruik van brandhout en het voorkomen van kopergroenvergiftiging.

Het diëet bestond uit gort voor 's morgens en boonen voor 's middags; af en toe werd de volgorde omgekeerd, „voor afwisse„ling". Door de gort werd fijn gesneden en te voren uitgeverscht spek gemengd (18 à 20 \&6 voor 400 koppen), de boonen werden met een weinig limoensap of palmolie toebereid. Het Compagnies rantsoen werd als „verhittend" aangemerkt en daarom kregen de slaven wat tamarinde in het drinkwater, tevens een voorbehoedmiddel tegen scheurbuik.

Het logies der slaven werd iederen dag gereinigd; de „vuile "lucht" verdreef men door heeten azijn te sprenkelen, wat buskruit te verbranden, of pik te doen koken.

Het drinkwatervoorziening was natuurlijk een probleem; blijkens de keukenvoorschriften waren transporten van 400 personen niet abnormaal. $\mathrm{Na}$ ieder der beide maaltijden werd gelegenheid tot drinken gegeven, tusschentijds slechts bij uitzondering. Dat de slaven probeerden zeewater te drinken, was blijkbaar niet ongewoon; volgens voorschrift immers moest hun dit belet worden, om het optreden van „loop” (dysenterie) te voorkomen. Na aankomst op Curaçao moesten de negers geleidelijk aan het drinkwater aldaar gewend worden.

Aan de zieken moest alle „liefde en mededoogen" worden bewezen; zij moesten van de gezonden worden gescheiden. Tegen bisco (framboesia?) werden zitbaden van zeewater aanbevolen, tegen den loop gebrande boonen.

Dat en hoe er, althans in het latere deel der $18 \mathrm{e}$ eeuw, voor deskundige medische hulp aan boord gezorgd werd, blijkt uit de "Noodige onderrichtingen" van D. H. Gallandat (bij Pieter Gillisen, Middelburg, 1769). 
Sluikhandel. Bekend is dat Portugeezen en Spanjaarden vóór 1580 aan hun eigen koloniale monopoliestelsel afbreuk deden, door met Nederlanders in compagnieschap te handelen, ook wel door Nederlandsche schepen van Oporto naar Brazilië te zenden en door van de diensten van Nederlandsche commiezen, supercargo's enz. gebruik te maken. En toen de Flamencos in 1634 Curaçao in bezit genomen hadden, verschaften zij een welkom correctief op het Spaansch monopoliestelsel, waardoor op het tegenoverliggende vasteland de tropische landbouw niet tot ontwikkeling had kunnen komen.

Intusschen zal daarna de handel van Nederland met Spaansch Amerika, door tusschenkomst van Spanjaarden, wel niet hebben opgehouden; althans in het begin der 18e eeuw bestond die handel nog. Le Long (Koophandel van Amsterdam) zegt dat onze Spaansche handel van weinig belang zou zijn, ware het niet dat via Cadix met de Spaansche koloniën in Amerika zaken konden worden gedaan, importzaken zoowel als exportzaken. Met de gallioenen, die regelmatig naar de West gingen, voeren z.g. naviganten mede, door wier tusschenkomst Hollandsche huizen aan den handel op de Spaansche koloniën deelnamen.

De Curaçaosche sluikhandel van ná den kolonialen tijd corrigeerde niet meer een monopoliestelsel, doch kwam eenvoudig neer op ontduiking van invoerrechten, voornaamste bron van inkomsten der jonge republieken. Ds. Bosch vertelt hoe bijzonder gunstig Bonaire gesitueerd was ten aanzien van den smokkelhandel op Puerto Cabello; men maakte eerst zijn lading vrij en ging dan 's nachts naar Bonaire, om meer te halen; het meerdere werd dan natuurlijk niet vertold.

Stokvischhout. (Brasil-, Campêche-, St. Martenshout).

Brasile, brasilium, is de naam der kleur van de verfstof, onttrokken aan het hout waarnaar Brazilië, het land, later genoemd werd; dat hout kwam ook uit de Golf van Campêche en van San Martin in Nieuw-Spanje (Mexico). Hoe echter onze voorouders aan den naam stokvischhout kwamen, is allerminst duidelijk.

Misschien werd het hout op dezelfde wijze in het schip gestuwd als stokvisch, destijds een belangrijk onderdeel der scheepsvictualia. Stokvisch mocht niet voor stuwage worden gebruikt en bij verzending naar de kust van Guiné moest de equipage de koppen en de staarten op de reis consumeeren (Notulen der X, 1694). Ook behoorden stokvischbeuken en verfhout klein maken beide tot de minder geliefde bezigheden aan boord der schepen. 
Tobago. In 1632 deden een 200 tal Zeeuwen een poging tot koloniseeren (W. R. Menkman, Geschiedk. Atlas van Nederland; West-Indië; Het eiland Tobago). Zie Westergaard: The Danish West Indies.

Een andere Zeeuwsche expeditie, die van Jan de Moor (Kesler, West-Indische Gids, X, 530) was daaraan echter voorafgegaan; in 1628 vertrokken 63 kolonisten naar Tobago, met het schip Fortuyn, kapitein Galeyn van Stapels, Kamer van Zeeland (De Laet bldz. 124).

Newton (The European nations in the West-Indies) teekent bij den aanval der Spanjaarden op Tobago aan: „where a party of „Dutchmen (apparently the first European settlers) were planting „tobacco".

Tortola. In den Geschiedkundigen Atlas van Nederland (WestIndië, Beneden- en Bovenwindsche Eilanden, 66) staat dat de Nederlanders in 1666 van dit eiland verdreven werden; dit jaartal berust op een drukfout en had 1660 moeten zijn.

Tumble down Dick, de naam van een baai in het N.W. van StEustatius.

In de $17 \mathrm{e}$ eeuw schreef men Dommelendijk, in de 18e Tommelendijk en Tumble down Dick kan moeilijk iets anders zijn dan een verengelsching van dezen laatsten naam. Een geval van volksetymologie, even aardig als de verhollandsching van Appendages tot Apendans in den Haag.

Hoe echter zijn de eerste Nederlandsche kolonisten op St. Eustatius aan Dommelendijk gekomen? Als Zeeuwsche of Hollandsche plaatsnaam is dat woord niet te vinden, als persoonsnaam evenmin.

Een variatie op slaperdijk? Maar waarom zou men op St. Eustatius waterkeeringswerken hebben aangelegd?

Een viertal jaren geleden kwam in de Saturday Evening Post een verhaaltje voor, genaamd Tumble Down Dick, dat blijkbaar op St. Eustatius speelde in het begin der 19e eeuw en waarin een geheimzinnige Française optrad, de weduwe Leclerc, onder een anderen naam.

$\mathrm{Nu}$ is de generaal Leclerc in 1802 op St. Domingue gestorven en Pauline Bonaparte huwde opnieuw in 1803, met Camille Borghèse; veel tijd om op St. Eustatius een rol te spelen had zij dus niet.

De Amerikaansche auteur, ter verantwoording geroepen, er- 
kende dat zijn verhaaltje niets met geschiedenis te maken had en dat hij geen recht had gehad Marie-Pauline op St. Eustatius te laten optreden.

De naam Le Clerque intusschen bleek op St. Eustatius wel bekend, als dien van een vroegeren bewoner, geen Statiaan, maar iemand afkomstig van Fransch Sint Martin.

Urbina-incident 1929. Over honderd jaar zullen snuffelaars zich kunnen verbazen over de eigenaardige voorlichting, welke aanvankelijk, van officieele zijde en door de pers, over dit geval gegeven werd.

De overval had plaats op Zaterdag 8 Juni, des avonds tusschen 9 u. en 9 u. 30 ; een 40 tal personen, aanvankelijk nagenoeg zonder vuurwapenen, namen er aan deel. De beide naar Venezuela medegevoerde gijzelaars - gouverneur en troepencommandant - waren Zondagsnamiddags omstreeks 7 uur op Curaçao terug.

De avondbladen in Nederland van Maandag 10 Juni publiceerden een communiqué van het departement van Koloniën van dien zelfden dag, waarin nog sprake was van een gewapende bende van naar schatting 500 man, welke „met blijkbaar tegen „de Venezolaansche regeering gerichte bedoelingen de militaire „politiemacht te Willemstad overvallen had." Het verband tusschen die aperte bedoeling en het toegepaste middel, moest de lezer zoeken in de mededeeling, dat de bende het munitiemagazijn der kazerne had geplunderd.

De bende zou den gezagvoerder van een in de haven liggend schip hebben gedwongen haar naar Venezuela over te brengen; in de werkelijkheid was het Amerikaansche stoomschip in kwestie door tusschenkomst van den gouverneur, na een met de bendeleiders gemaakt accoord, gerequireerd. Was dit laatste geschied om te voldoen aan de bepaling van het regeeringsreglement dat bij oorlog of opstand de gouverneur de maatregelen neemt welk „door den nood" geboden worden?

De bende zou volgens het communiqué kans gezien hebben gouverneur en troepencommandant bij verrassing „op te lichten” en hen, tezamen met „enkele” militairen, aan boord van het schip te brengen. In de werkelijkheid scheepte men zich 3 à 4 uur na den overval in, medevoerende den gouverneur en den commandant, die beiden van den aanvang af met de aanvoerders der Venezolanen onderhandeld hadden - en die alleen nog maar verrast kunnen zijn geworden door de mededeeling dat men hen als gijzelaars mede zou nemen - alsmede elf Nederlandsche militairen. 
De zeer belangrijke vraag (de gouverneur neemt volgens het regeeringsreglement maatregelen tegen aanranding „van buiten”) of men te doen had gehad met een op het eiland gelande bende, dan wel met eene welke zich uit de reeds op het eiland aanwezige vreemdelingen had gevormd, een vraag welke in de particuliere persberichten in het midden was gelaten, werd door het regeeringscommuniqué niet beantwoord, hoewel het ministerie den geheele afgeloopen nacht, van 9 op 10 Juni, ongestoord, door middel van het gouvernements radiostation op Curaçao, met de autoriteiten aldaar verbinding had gehad. Van den geheelen afgeloopen Zondag (d.w.z. van af Zondagmorgen 2 uur, toen de bende vertrokken en het radiostation weder vrij was) werd niet gesproken. Dien Zondag waren de gouverneur en de commandant tot des avonds 7 uur afwezig geweest, maar procureur-generaal, gouvernements secretaris en de beide subalterne officieren van het garnizoen waren gebleven; wanneer het ministerie van het gebeurde bericht had ontvangen werd niet gepubliceerd. Er mag toch niet aangenomen worden, dat het in het departementsgebouw ingerichte radiostation wel des nachts, maar niet des Zondags bezet was, of dat men op Curaçao met de berichtgeving zal hebben gewacht, totdat de gouverneur weder terug zou zijn.

Op 11 December 1929, zes maanden na den overval, wist de minister van Koloniën, op een vraag van een lid der Tweede Kamer nopens de komst van Urbina op Curaçao, niets definitievers te antwoorden dan dat genoemde Venezolaan „waarschijn„lijk" een paar dagen te voren onder een valschen naam en met valsche papieren was gearriveerd. Urbina's luitenant, Gustavo Machado, vertelde later in zijn brochure (El Asalto a Curaçao) dat de aanvoerder op 31 Mei met het ss. Buenos Ayres aangekomen en zonder moeite geland was. De mededeeling van den minister sloot in, dat destijds op Curaçao een passencontrole bestond, ook voor eerste klasse passagiers; die van Machado doet vermoeden - waarschijnlijk terecht - dat zulks niet het geval was.

Op 10 April 1930 vroeg de Kol. Raad (Voorl. verslag begrooting 1931) om overlegging van het rapport der commissie-Hoorweg, welke naar aanleiding van het Urbinageval ter plaatse een onderzoek had ingesteld, of althans van dat gedeelte van het verslag, hetwelk de minister van Koloniën op 23 November 1929 aan de Tweede Kamer had doen toekomen. Bij memorie van antwoord verklaarde het Bestuur dat het bedoelde gedeeltelijke rapport „niet in de archieven op Curaçao aanwezig was”, zoodat aan het verzoek van den Raad niet voldaan kon worden. 
De rapporten van gouverneur en troepencommandant waren 18 Sept. 1929 bij de Eerste en twee dagen later bij de Tweede Kamer binnen gekomen; zij waren direct na het gebeurde opgesteld, hadden blijkbaar geen groote waarde en kwamen niet voor publicatie in aanmerking. Het volledige rapport Hoorweg is evenmin publiek gemaakt.

Waarschijnlijk niet eerder dan twee en een half jaar na dato verscheen te Barcelona in Spanje de brochure van Silva en Machado (zie Het Vaderland, 14 en 20 October 1932), welke een verrassend nieuw licht wierp op de politiek van het handjevol agitatoren dat de leiding had en op hunne bedoelingen, op de atmospheer waarin de aanslag werd voorbereid en op de rol welke Rafael Simón Urbina daarbij gespeeld - of liever niet gespeeld heeft. „El asalto” moge met betrekking tot Venezolaansche en Curaçaosche toestanden veel bevatten dat onjuist, of misleidend is, op de hierboven genoemde punten is het brochuretje allicht betrouwbaar; er bestaat geen goede reden om daaraan te twijfelen.

Berichten juist aangaande deze punten hebben van Nederlandsche zijde (overheid, pers of particuliere publicisten) ten eene male ontbroken.

De Curaçaosche pers heeft, zooals ook elders is opgemerkt, al heel weinig belangrijks gegeven aangaande den overval, of aangaande de wijze waarop het moederland op de gebeurtenis heeft gereageerd. De Amigoe di Curaçao (nummer van 22 Juni 1929) citeerde uit De Telegraaf dat in den aanslag een consequentie moest worden gezien van de ,scheepvaart"-politiek in Nederland. In een ander nummer wist het Curaçaosche blad zijn lezers te berichten dat het Eerste Kamerlid Colijn ter zake van het gebeurde een „bulletin” tot den minister had gericht.

Verovering, van Curaçao. Verschillende schrijvers hebben 4 Mei genoemd als den dag waarop het eskadertje van 1634 ter verovering van Curaçao uitvoer (van welke plaats in Nederland?) Deze datum komt ook voor bij De Laet (pag. 430).

Een rapport van Van Walbeeck is niet meer beschikbaar; dat van Le Grand echter bevestigt de juistheid der datums: 6 Juli (eerste aankomst op Bonaire), 26 Juli (tweede dito), 29 Juli (aankomst op Curaçao), 31 Juli (landing op Curaçao), 21 Augustus (accoord met De Morla).

De door Van Paddenburgh genoemde datum 25 Juni 1634, wellicht overgenomen uit Hering (Beschrijving van het eiland Curaçao) slaat nergens op. 
De Spaansche documentatie geeft eenigszins andere datums.

Vespucci. Het eiland Curaçao wordt gezegd in 1499 door Amerigo Vespucci te zijn ontdekt (W. R. Menkman, Onze West; Curaçao). Amerigo Vespucci, die voor den ontdekker van Curaçao wordt gehouden (dezelfde, Geschiedkundige Atlas van Nederland; West-Indië; Het eiland Curaçao). $\mathrm{Er}$ is mij wel eens gevraagd door wie(n) V. voor den ontdekker wordt gehouden. Ik zou helaas geen meer gezaghebbend schrijver weten te noemen dan Fred. A. Ober (A guide to the West Indies). De abt De la Porte (136e brief, 12 Maart 1751) zegt van de kust van Venezuela „Ojeda et Vespuce la découvrèrent à la fin du quinzième Siècle"; later spreekt hij van deze beide personen als „cet Italien et Ojeda „son admiral”.

Van Vespucci is veel minder bekend dan men zou wenschen, maar óver hem is veel getwist; Baralt (Venezolaan) noemt hem „un oscuro aventurero", Varnhagen (Braziliaan) neemt het voor hem op. De eer van het eerst het vasteland der nieuwe wereld te hebben gezien (het gaat tusschen hem, Columbus en Cabot) wordt hem betwist en ook de ontdekking van onze Benedenwindsche eilanden gunt men hem niet. Intusschen heeft Waldseemüller (Martis Ilacomylus) het nieuwe werelddeel naar hem genoemd en daarmede kan Vespucci het wel doen.

De Florentijner zelf beweerde, in 1497 voor een reis naar de Westelijke wereld te zijn uitgevaren en De Varnhagen (Premier voyage de Amerígo Vespucci, Weenen 1869) betoogde dat zijn held op die reis heelemaal niet in de Golf van Paria en op de kust van Venezuela kan zijn geweest, maar dat zijn verhaal betrekking moet hebben gehad op de Golf van Mexico, de kust van Honduras ,Yucatán en Florida. Curaçao zou dan het eerst door Europeanen zijn gezien op de reis van Alonso de Ojeda van 1499, waaraan Vespucci en De la Cosa (de kaartteekenaar) deelnamen.

Wanneer Vespucci's aanspraak op de eer Curaçao te hebben ontdekt, alleen steunt op zijn brief aan de Medicis, waar in het verhaal voorkomt van het eiland waar iedere vrouw een Penthesilea en ieder man een Antaeus leek, dan is die aanspraak inderdaad niet sterk. Is die van Ojeda echter zooveel beter?

Ook op latere reizen hebben de bevelhebbers der expedities zich niet altijd als de ontdekkers doen gelden van al het nieuwe dat onderweg bekend werd. Pitcairn Island in de Stille Zuidzee en Puget Sound aan de Westkust van Noord-Amerika b.v. ont- 
leenen zelfs hun namen aan veel obscuurder zeevaarders dan Vespucci was.

Vlag, Amerikaansche. Dat de vlag van het Amerikaansche gemeenebest voor het eerst zou zijn gesalueerd toen de kaper Andrea Doria op 16 November 1776 ter reede van St. Eustatius aankwam, is voor de Yankees een soort credo geworden.

Captain Colpoys schreef echter op 27 November 1776 aan den vice-admiraal Young, dat zoowel op St. Kruis als op St. Eustatius het saluut der Amerikaansche gearmeerde vaartuigen beantwoord werd en de commander in chief had reeds uit een brief van 27 October 1776 kunnen lezen, dat een schip onder de Amerikaansche vlag op St. Kruis was gesalueerd (door Edler en Jameson medegedeeld uit de Sparks Mss en de Maryland Archives). Het bezwaar der Engelsche autoriteiten gold niet het salueeren van Amerikaansche schepen, maar van de vlag die zij voerden en dat was zeker niet de Engelsche.

Dat wij niet zouden weten hoe die eerste Amerikaansche vlag er uitgezien heeft (Ober, Guide to the West Indies )is niet juist; dat het een vlag met 13 horizontale strepen was (de sterren kwamen later) is door verschillende ooggetuigen medegedeeld (W. R. Menkman, West-Indische Gids XV, 325, 326).

Vlag, Fransche. Brusse (Curaçao en zijn bewoners, 1882) zegt ergens dat op Curaçao na de omwenteling van 1795 aan den havenmond eenigen tijd de Fransche vlag naast de Hollandsche heeft gewaaid; jammer genoeg echter vertelt de schrijver er niet bij hoe hij dit te weten is gekomen. De directeur Jan Jacob Beaujon was om zijn Engelschgezindheid bekend.

Vlag, Nederlandsche. Ook op onze Westindische eilanden is tot laat in de $18 \mathrm{e}$ eeuw nog van de Princevlag gesproken, wat echter de rood-wit-blauwe vlag was.

Cornelius de Jong, die in 1780 naar de West voer, vertelt van een begrafenis aan den wal, waarbij de Hollandsche of z.g. Prinsevlag over de lijkkist was gelegd, zoodat de kleuren - rood, wit en blauw - te zien waren. Op blz. 192 echter lezen wij dat bij de aankomst op St. Eustatius (Februari 1781) van de Mars en het convooi, door de Engelschen opgebracht, de vlaggen omgekeerd geheschen moesten worden, het rood of oranje onder. Dat Nederlandsche koopvaardijschepen destijds of rood, wit en blauwe, of oranje, wit en blauwe vlaggen voerden,mag nauwelijks worden 
verondersteld. Wij moeten eerder begrijpen dat het rood onzer vlag zelfs toen nog ook wel oranje werd genoemd.

De resolutie van H. H. M. van 14 Februari 1796, betreffende de nationale vlag, bepaalde, dat deze zou zijn ,de gewoone en „altoos in gebruik geweest zijnde Bataafsche of z.g. Hollandsche "vlag". Een prent in kleuren van standaard en wimpel was aan de resolutie toegevoegd; daarop is voor de bovenste baan der vlag een kleur aangegeven, welke wij tegenwoordig zonder eenige aarzeling rood noemen, hetzelfde rood dat thans nog in onze officieele vlag voorkomt.

Vlag, U.S.A. De tegenwoordige Amerikaansche vlag heeft in de jongste Curaçaosche geschiedenis twee maal een eigenaardige rol gespeeld.

Op 17 Juli 1922 werd zij, bij de stakingsonlusten in de haven, door of op aandringen van Venezolanen geheschen, toen deze hun leven bedreigd achtten door inheemsche ontevredenen.

En in den nacht van Urbina (8/9 Juni 1929) werden gouverneur, militairen en wapentuig onder de Amerikaansche vlag weggevoerd, d.w.z. met een Amerikaansch schip (s.s. Maracaibo); men vertrok bij donker en dus zonder vlag en op zee voert een koopvaardijschip geen vlag. Of de Maracaibo des ochtends bij de ontscheping, op Venezolaansch grondgebied, zijn natievlag heeft vertoond, vermeldt de geschiedenis niet, wel dat de wapenen en de roode vlaggen (door de revolutionnairen uit verscheurde Nederlandsche vlaggen gemaakt) de boot van den Venezolaanschen Resguardo deden aftrekken en dat de landing tot ongeveer 9 uur in den ochtend duurde (G. Machado, El asalto a Curaçao).

Vlag, vredes. Al kan niet meer worden vastgesteld of de beruchte achttiende eeuwsche flags of truce een speciale vlag voerden en hoe die er uitzag (W. R. Menkman, West-Indische Gids XIV, 381), zoo weten wij toch van Cornelius de Jong dat de Jonge David, het Nederlandsche koopvaardijschip, waarmede in 1781 de Nederlandsche krijgsgevangenen van St. Eustatius naar Europa werden gevoerd, wanneer men andere schepen ontmoette de Engelsche vlag vertoonde, met een wit bedlaken in den voortop, als teeken dat de J. D. een kartelschip was.

Tijdens den Oostenrijkschen successie-oorlog gaf de commandeur van St. Eustatius commissies aan meer dan 50 Fransche schepen (flags of truce?) om Iersche provisiën naar de Fransche eilanden te vervoeren (Pitnam, The development of the British 
West Indies). In denzelfden tijd werden in sommige Noordamerikaansche provincies flags of truce ten bate der autoriteiten verkocht (zelfde auteur).

Vruchten. Bontekoe „ververschte" zich in 1619 op een eiland in den Indischen Oceaan met „water-lemoenen en Spaens speck", Exquemelin vond in 1666 op Tortuga „Watermeloenen en Spaen„sche Meloenen" en nog heden ten dage verstaat men in Suriname onder meloen bij voorkeur watermeloen, terwijl men de canteloep (Cucurbita Melo) Spaansch spek noemt.

Deze laatste naam was althans in het begin der 19e eeuw ook op Curaçao bekend, want Van Paddenburgh (1819) noemt Spaansch spek onder de vruchten, op het eiland gegeten.

De vrucht der Musa sapientum was reeds bij de Nederlandsche zeevaarders van vroeg in de $17 \mathrm{e}$ eeuw als bacove (Sp. bacova) bekend en deze naam is in Suriname de algemeen gebruikelijke gebleven.

Dr. P. J. J. van Breemen (Gedenkboek Nederland-Curaçao 1634 - 1934, 257) geeft ook den Curaçaoschen naam als bakove en Van Paddenburgh spreekt van bacoves, doch voegt eraan toe banane of pisang.

Ook banana is een Spaansche naam, reeds zeer vroeg bij ons bekend en Multatuli behoefde er zich niet zoo over te verwonderen (aanteekeningen Max Havelaar) dat men dit „Westindische” woord in ons land beter verstond dan pisang. Reeds voor Douwes Dekker was koloniaal blijkbaar synoniem met Indisch. Het was hem een raadsel (zelfde aanteekeningen) hoe de Engelschen aan het woord plantain kwamen en het Spaansche plátano was hem dus blijkbaar ook niet bekend; voor een koloniaal specialiteit nogal vreemd.

Reeds vóór 1600 kwamen de Spaansche en de Portugeesche namen der „Indiaensche vygen” in de Nederlandsche litteratuur voor (annotaties van Dr. Paludanus op Linschoten's Itinerario).

Walbeeck - Johannes van - en Pierre Le Grand. Volgens Dr. F. W. Stapel (Curacaonummer Maandblad Oost en West) hadden beiden al vele jaren de Compagnie gediend ter kuste van Brazilië.

Voor zoover valt na te gaan kwam Van Walbeeck 20 April 1630 voor het eerst in Brazilië aan; Le Grand wordt in de Braziliaansche geschiedenis voor het eerst genoemd in verband met de expeditie naar Itamaracá in April 1631 en hij was vermoedelijk toen juist (op den 14en) met de vloot van Pater aangekomen. 
Welsers. In het contract van 27 Maart 1528 (aangevuld 4 April zelfde jaar) was geen sprake van de Welsers, maar van Heinrich Ehinger en Hieronymus Sailer. Het huis Ehinger te Konstanz echter moet zeker deelgenoote der Welsers in de Venezolaansche onderneming zijn geweest. H. E. en H. S. waren de vertegenwoordigers in Spanje der Welsersche ondernemingen; zij droegen in 1531 hun rechten over op Bartholomeus en Anton Welser (ratificatie te Sevilla 17 Februari 1531). De onderneming was van den beginne af inderdaad een Welsersche geweest.

Het exploitatiegebied werd in het contract omschreven als de provincie Venezuela „y cabo de la Vela”; de oostgrens was Kaap Maracapana, (Golf van Cariaco, tusschen het schiereiland van Araya en de vaste kust van Venezuela), de westgrens kaap La Vela, de zuidgrens was onbepaald. De Curaçaosche eilanden waren uitdrukkelijk uitgesloten (zie Ampués).

De eerste Europeesche avonturiers kwamen met vier schepen onder Garcia de Lerma op Española aan; de reis naar de kust van Coro werd voortgezet met drie schepen onder Ambrosius Ehinger (Ambrosio de Alfinger), zie onder Ampués.

De heerschappij der Augsburgers kan geacht worden officieel een einde te hebben genomen met de beslissing van 's Konings Indischen raad van 13 April 1556, waarbij de Welsers van die heerschappij vervallen werden verklaard, maar waarbij zij tevens van allerlei aantijgingen werden gezuiverd. Te voren echter hadden zij reeds geruimen tijd de macht niet meer uitgeoefend en was er niet door hen, maar niettegenstaande hen geregeerd; ook na 1556 evenwel bleven zij nog op hun rechten staan.

Konrad Häbler, aan wiens boek (Die überseeischen Unternehmungen der Welser und ihrer Gesellschafter, Leipzig 1903) bovenstaande bijzonderheden zijn ontleend, acht ook de Venezolaansche onderneming der Welsers een prachtig staaltje van 16e eeuwschen Duitschen ondernemingsgeest; Spaansche, Venezolaansche en andere historici beschouwen het contract van 1528 als fataal en de uitvoering als ruineus voor het land en de bevolking.

West-Indische Compagnie. Het uitvoerende bewind berustte bij de Oost-Indische Compagnie bij de XVII. Bij de eerste WestIndische Comp. was het overeenkomstige college dat der XIX, bij de tweede dat der X.

In de West-Indische Gids van Juli-Augustus 1934 (Bibliographie) staat abusievelijk Heeren XVII; moet zijn Heeren XIX.

West-Indische Gids XVII 


\section{SPROKKELINGEN OP HET TERREIN DER GESCHIEDENIS}

Zending. Ds. Joh. Rauws meent dat in 1634 de indiaansche bevolking van Curaçao (en van de beide ander Benedenwindsche eilanden?), volgens een destijds algemeen aanvaarden regel, geacht werd tot het Protestantisme te zijn overgegaan (Curaçaonummer Oost en West, Mei 1934).

Wat dan echter niet belet heeft, dat men min of meer oogluikend toestond aan R.K. priesters in den omtrek om op onze eilanden aan de R.K. inwoners hun zorgen te wijden. P. J. V. (Monseigneur Verriet) erkent dit in het Gedenkboek Nederland-Curaçao 1634-1934, maar lost de vraag niet op of deze verdraagzaamheid, onverschilligheid, of berekening, van den aanvang af de houding der plaatselijke autoriteiten gekenmerkt heeft. Uit de doopboeken (Curaçao stond sedert 1599 onder de geestelijke rechtsmacht van den Bisschop van Caracas) ware dit misschien na te gaan.

Volgens Mgr. V. was de tweede Compagnie, met betrekking tot de anti-roomsche politiek, heel wat gematigder dan de eerste was geweest. In 1669 echter bestond de oude Compagnie nog en Exquemelin vertelt ons van de Indianen op Aruba dat zij „van „wege de Religie onder de Spaanschen" stonden. Hij verhaalt verder: „alle jaren komt daer” (op Aruba) „een Spaensch Pries„ter, van een Dorp, daar teghen over aen de vaste Kust, ghe„naemt Coro, die haer predickt, en het Sacrament nae de Room"sche wijse uytdeelt".

Mgr. Verriet brengt hulde aan de Spaansche priesters die vóór 1634 op Curaçao werkten; de in 1642 opgetreden Ds. Corn. Backer echter vond de nog aanwezige Indianen wèl verlangend naar den doop voor hunne kinderen (welke dan door den predikant werd verricht), maar overigens in heidenschen staat levend (Knappert, Gedenkboek Nederland-Curaçao, 35, 36).

De instructie van 1638 voor de predikanten der West-Indische Compagnie (Ds. Rauws, Curaçaonummer Oost en West en ProfDr. L. Knappert, W. I. Gids XII, 37) droeg hun de zorg op voor Spanjaarden, Portugeezen, Indianen en negers; algemeen wordt aangenomen dat zij zich aan dit deel hunner herderlijke taak bitter weinig gelegen lieten liggen.

Waren de Westindische predikanten zooveel minder ijverig dan die in ander Nederlandsch koloniaal gebied, waar wèl zendingswerk verricht is (Oost-Indië, Ceylon, kust van Afrika)? In Brazilië trouwens ook, waar de predikanten de in 1636 door Joan Maurits (conform de regeeringsordonnantie van 1629) ingevoerde godsdienstvrijheid in 1638 weder beperkt wisten te krijgen en 
waar de Prot. geestelijken ook Indianen kerstenden (Netscher, Hollandais au Brésil.)

Zou het geheim der afzijdigheid tegenover Westindische negers niet gelegen zijn in de slavernij, in de bijzondere positie der slaven en die van de meesters?

Het is bekend, dat op Curaçao de Protestantsche meesters de slavenkinderen Roomsch, de Joodsche meesters die kinderen ook wel eens Protestantsch lieten doopen (Gedenkboek NederlandCuraçao, 77).

Volgens Ds. Bosch zagen de blanken in protestantisme onder slaven een gevaar voor het koloniaal stelsel. Hij zelf zou het hebben kunnen toejuichen, dat de Methodisten (indien die maar minder dweepziek geweest waren) aan de negers een eigen protestantisme gebracht hadden, buiten de Ned. Hervormde kerk, zooals de Herrnhutters in Suriname hebben gedaan.

Père Labat, die heel in het begin der $18 \mathrm{e}$ eeuw onze Bovenwindsche eilanden bezocht, legt een zeer gunstig getuigenis af aangaande de wijze waarop de Hollanders hun slaven „onderhielden "in de Christelijke religie”; deze lof echter zal wel in de eerste plaats verdiend zijn door de gemakkelijkheid waarmede de slaven aan de Roomsche kerk werden overgelaten.

Volgens Labat redeneerden de Engelsche predikanten, dat slaven niet gedoopt konden worden, omdat men zijn broeders in Christus niet in slavernij zou mogen houden.

De plaats welke de slaaf innam in het Christelijk denken van het laatst der $17 \mathrm{e}$ en het eerste stuk der 18e eeuw, was blijkbaar bij Protestanten een andere dan bij Roomsch-Katholieken. 